30

\title{
Phytoene Synthase 2 Can Compensate for the Absence of Psy1 in Pepper Fruit (Capsicum annuum)
}

So-Jeong Jang ${ }^{1 *}$, Hyo-Bong Jeong ${ }^{1 *}$, Ayoung Jung ${ }^{1}$, Min-Young Kang ${ }^{1}$, Suna Kim², SunHwa $\mathrm{Ha}^{3}$, Jin-Kyung Kwon ${ }^{1}$, and Byoung-Cheorl Kang ${ }^{1,4}$

${ }^{1}$ Department of Plant Science, Plant Genomics \& Breeding Institute, and Research Institute of Agriculture and Life Sciences, Seoul National University, Seoul 151-921, Republic of Korea

${ }^{2}$ Food and Nutrition in Home Economics, Korea National Open University, 169 DongsungDong, Jongno-Gu, Seoul 110-791, Republic of Korea

${ }^{3}$ Department of Genetic Engineering and Graduate School of Biotechnology, College of Life Sciences, Kyung Hee University, Giheung-gu, Yongin-si, Gyeonggi-do 17104, Republic of Korea

${ }^{4}$ Institutes of Green-bio Science and Technology, Seoul National University, Pyeongchang 232-916, Republic of Korea

\section{Author information}

*These authors equally contributed

So-Jeong Jang, E-mail: liaria@snu.ac.kr

Hyo-Bong Jeong, E-mail: gyqhd7718@snu.ac.kr

5 Ayoung Jung, E-mail: ayoung0673@gmail.com

26 Min-Young Kang, E-mail: kmyjj3802@hanmail.net

27 Suna Kim, E-mail: ksuna7@mail.knou.ac.kr

28 Sun-Hwa Ha, E-mail: sunhwa@khu.ac.kr

29 Jin-Kyung Kwon, E-mail: kwonjk@snu.ac.kr

1 Corresponding author

32 Byoung-Cheorl Kang, E-mail: bk54@snu.ac.kr; Tel: 82-2-880-4563; Fax: 82-2-873-2056 
bioRxiv preprint doi: https://doi.org/10.1101/797977; this version posted October 8,2019 . The copyright holder for this preprint (which was not certified by peer review) is the author/funder, who has granted bioRxiv a license to display the preprint in perpetuity. It is made available under aCC-BY-NC-ND 4.0 International license.

\footnotetext{
Functional analysis of Phytoene synthase 2 in pepper fruit
}

33

34 Date of submission: October 8, 2019

35 Number of tables: 3

36 Number of figures: 7

37 Word count: 6,494

38 Number of supplementary tables: 1

39 Number of supplementary figures: 5 
bioRxiv preprint doi: https://doi.org/10.1101/797977; this version posted October 8,2019 . The copyright holder for this preprint (which was not certified by peer review) is the author/funder, who has granted bioRxiv a license to display the preprint in perpetuity. It is made available under aCC-BY-NC-ND 4.0 International license.

\footnotetext{
Functional analysis of Phytoene synthase 2 in pepper fruit
}

\section{$40 \quad$ Highlight}

41 We reveal the novel function of PSY2 in the development of yellow pepper fruit coloration

42 using a psyl knockout mutant. This gene function was not previously identified in 43 solanaceous crops.

44 


\section{Abstract}

$46 \quad$ Phytoene synthase 1 (PSY1) and Capsanthin-capsorubin synthase (CCS) are two major genes

47 responsible for fruit color variation in pepper (Capsicum spp.), although fruit colors cannot

48 be explained by variations in these two genes alone. Furthermore, the role of PSY2 in fruit

49 color development in pepper is unknown. Here, we used a systemic approach to discover the

50 genetic factors responsible for the yellow fruit color of C. annuиm 'MicroPep Yellow' (MY)

51 and to reveal the role of PSY2 in fruit color. We detected a complete deletion of PSY1 and a

52 retrotransposon insertion in CCS in MY. Despite the loss of PSY1 and CCS function, the MY

53 and mutant $\mathrm{F}_{2}$ plants from a cross between MY and the MicroPep Red (MR) accumulated

54 basal levels of carotenoids, indicating that other PSY genes may complement the loss of PSY1.

55 A qRT-PCR analysis demonstrated that PSY2 is constitutively expressed in both MR and MY

56 fruits, and a color complementation assay using Escherichia coli revealed that PSY2 is

57 capable of biosynthesizing a carotenoid. Virus-induced gene silencing of PSY2 in MY

58 resulted in white fruits. These findings suggest that PSY2 can compensate for the absence of

59 PSY1 in fruit, resulting in the yellow color of MY fruits.

60

61 Key words: capsanthin-capsorubin synthase, carotenoid, color complementation, mature fruit

62 color, pepper (Capsicum spp.), phytoene synthase, virus-induced gene silencing (VIGS). 


\section{Introduction}

Peppers (Capsicum spp.) are one of the most popular fruits in the world. Among the traits of pepper fruits, color is one of the most important for its aesthetic value and nutritional benefits. The distinct colors of mature fruits result from the chloroplast-to-chromoplast conversion during fruit ripening. Since chromoplasts possess a higher capacity to biosynthesize and sequester carotenoids than chloroplasts, mature pepper fruits often display ivory to red colors depending on chromoplast development and carotenoid biosynthesis (Sun et al., 2018). Carotenoids belong to a group of tetraterpenoids derived from eight isoprene units, thus contain 40 carbons in their polyene backbone (Jackson et al., 2008). Carotenoids are essential for human nutrition and health as they provide a dietary source of provitamin A and serve as antioxidants to reduce the incidence of many diseases, including cardiovascular diseases and cancers (Fraser and Bramley, 2004). Carotenoids also play essential roles in plants, functioning in photosynthesis and photo-protection, and providing precursors for phytohormones such as abscisic acid and strigolactones (Nambara and Marion-Poll, 2005; Domonkos et al., 2013; Al-Babili and Bouwmeester, 2015).

Carotenoid biosynthesis begins with the formation of phytoene, catalyzed by PSY. There are at least two PSY genes in plants except Arabidopsis thaliana, which only has a single PSY gene. Multiple $P S Y$ genes in one plant can explain different carotenogenesis in various tissues; for example, in tomato (Solanum lycopersicum), PSY1 functions in the fruits, PSY2 in the leaves, and PSY3 in the roots (Fantini et al., 2013, Wang et al., 2014; Yuan et al., 2015). Following a series of desaturation and isomerization steps, phytoene is converted into lycopene, which is the major carotenoid component in mature tomato fruits. By contrast, the red color of pepper fruits is caused by the accumulation of capsanthin and capsorubin, which derived from lycopene (Paran and van der Knaap, 2007). This pepper-specific process is regulated by $\mathrm{CCS}$, which converts antheraxanthin and violaxanthin into capsanthin and capsorubin, respectively (Bouvier et al., 1994).

The three-locus model $(C 1, C 2$, and $Y$ ) was proposed to explain the color variation in pepper fruits (Hurtado-Hernandez and Smith, 1985). In this model, mature fruit colors can be classified into eight groups according to the allelic combinations of three genes: from white $\left(\begin{array}{lll}c 1 & c 2 & y\end{array}\right)$ to red $(C 1 C 2 \quad Y$ ). An analysis of candidate carotenoid biosynthetic genes revealed 
that the $C 2$ and $Y$ loci encode $P S Y 1$ and $C C S$, respectively (Lefebvre et al., 1998; Popovsky and Paran 2000; Huh et al., 2001); however, the third locus, C1, is yet to be characterized. Since the identification of the genes encoded by the $C 2$ and $Y$ loci, many studies have explored the color variation in pepper fruits based on the allelic variations of PSY and CCS. In general, peppers with yellow fruit have structural mutations in the coding region of $C C S$ that lead to a premature stop codon (Lefebvre et al., 1998; Popovsky and Paran 2000; Ha et al., 2007; Li et al., 2013). The early translational termination of CCS can also result in orange fruit, as was observed in C. апnиum 'Fogo' (Guzman et al., 2010). By contrast, Kim et al. (2010) revealed that a splicing mutation in PSY1 impairs the activity of its enzyme product and leads to orange bonnet pepper fruits (C. chinense 'Habanero'). Despite this, allelic variations of $P S Y$ and $C C S$ cannot fully explain the differences in fruit color across all pepper accessions, as Jeong et al. (2018) previously described. Therefore, identification of the last color-determining gene, $C 1$, is necessary for solving the riddle of fruit color variations in pepper.

To identify $C l$ and validate the three-locus model for fruit color variation in pepper, studies have investigated the roles of other carotenoid biosynthetic genes. The VIGS analysis of capsanthin biosynthetic genes in detached red pepper fruits showed that, in addition to PSYI and CCS, lycopene $\beta$-cyclase (Lcyb) and $\beta$-carotene hydroxylase (CrtZ-2) were also required for the formation of the normal red color (Tian et al., 2014). In addition, Borovsky et al. (2013) reported that an ethyl methanesulfonate (EMS)-induced nucleotide substitution in CrtZ-2 coding region led to the conversion of red into orange fruits in C. annuum 'Maor'. Despite this, natural mutations of these genes have not been identified, therefore they are not candidates of the $C 1$ locus.

The carotenoid biosynthetic pathways and the functions of the genes involved have been elucidated using strains of Escherichia coli as heterologous hosts, in a so-called color complementation assay (Perry et al., 1986; Cunningham and Gantt, 2007). The pAC-BETA vector contains the $\operatorname{crtE}, \mathrm{crtB}, \mathrm{crtI}$, and $\operatorname{crt} Y$ carotenogenic genes from Erwinia herbicola, which can produce $\beta$-carotene when transformed into E. coli (Cunningham et al., 1996). By contrast, the pAC-85b vector does not contain $\operatorname{crtB}$, a homolog of $P S Y$, and when expressed in E. coli, $\beta$-carotene can only be produced when complemented with a gene encoding a PSY 
127 enzyme (Cunningham and Gantt, 2007). Through a complementation assay using pAC-85b,

128 the function of the PSY1 transcriptional variants of both barley (Hordeum vulgare) and 129 tomato has been revealed (Rodríguez-Suárez et al., 2011; Kang et al., 2014), and the catalytic 130 activities of multiple PSY enzymes were also analyzed in loquat (Eriobotrya japonica) (Fu et al., 2014). Moreover, using a color complementation test using the pAC-LYC construct, 132 which contain genes for lycopene production in papaya (Carica papaya), the role of Lcyb in 133 fruit flesh color was confirmed (Blas et al., 2010). To date, a wider range of carotenoid134 related enzymes, such as the carotenoid cleavage dioxygenases, have been analyzed using the 135 above-mentioned approach (Kim et al., 2013). However, PSY genes of pepper have not been analyzed by color complementation assay yet.

In this study, seven carotenoid biosynthetic genes were analyzed to discover the genetic factor regulating yellow fruit color in C. аппиит 'MicroPep Yellow' (MY). Among them, structural mutations in PSYI and CCS were identified in MY. Despite the associated functional knockout of PSY1, which catalyze the rate-limiting step of carotenoid biosynthesis,

142 basal levels of carotenoids were still detected in MY using ultra-performance liquid 143 chromatography (UPLC) analysis. We postulated that PSY2 may contribute to the formation 144 of the yellow color in MY fruits. To test this hypothesis, a qRT-PCR analysis of PSY2 145 expression and a color complementation assay was conducted. The VIGS of PSY2 was used 146 to confirm the function of this gene in MY. The result showed that PSY2 are expressed in all 147 stage of fruit and functionally active gene. Here, we suggest that PSY2 can compensate the 148 absence of PSY1 in pepper fruit. 
149 Materials and methods

150 Plant materials

151 C. апnиит accessions 'MicroPep Red (MR)' and 'MicroPep Yellow (MY)' were selected 152 from the germplasm of Horticultural Crops Breeding and Genetics lab (Seoul National 153 University, Republic of Korea). The mature fruits of MR and MY were red and yellow, 154 respectively (Fig. 1). A total of $281 \mathrm{~F}_{2}$ individuals were obtained from a cross between MR 155 and MY and grown at the greenhouse of Seoul National University (Suwon, Republic of 156 Korea).

\section{Nucleic acid extraction}

Genomic DNA (gDNA) was extracted from the young leaves of $F_{2}$ individuals from a cross between MR and MY, and of the parental lines, using a modified cetyltrimethylammonium bromide (CTAB) method (Porebski et al., 1997). Leaf tissues were homogenized using 3-mm steel beads with TissueLyserII (Qiagen, Hilden, Germany). The gDNA concentration were measured and diluted to $20 \mathrm{ng} / \mu \mathrm{L}$ for further experiments.

Total RNA was extracted from target tissues, immediately frozen in liquid nitrogen and ground into a fine powder. The RNA was extracted using a MG RNAzol kit (MGmed, Seoul, Republic of Korea), following manufacturer's instructions. The cDNA was synthesized from $2 \mu \mathrm{g}$ RNA using an EasyScript Reverse Transcriptase kit (TransGen, Beijing, China) with oligo(dT) primers. The resulting cDNAs were used for the expression analysis.

\section{Candidate gene analysis}

172 Reference sequences of seven carotenogenic genes in pepper were obtained from the Sol 173 Genomics Network (https://solgenomics.net/). PDS was not included as its mutation results in 174 distinct effect. The pepper PSY2 and PSY3 sequences have not been identified previously; 175 therefore, the tomato PSY2 and PSY3 sequences were BLAST-searched against the pepper 176 genome (CM334 v1.55). As a result, the CA02g20350 (92\% sequence identity with tomato PSY2; Solyc02g081330) and CA01g12040 (93\% sequence identity with tomato PSY3; Solyc01g005940) coding sequences were obtained. Primers were designed to amplify the full

179 length of these candidate genes (Table 1), and a PCR was performed using PrimeSTAR GXL 180 DNA polymerase (Takara Bio, Kusatsu, Japan). The resulting amplicons were separated on a 
181 1\% agarose gel and the DNA was recovered using a LaboPass PCR clean-up kit (Cosmo

182 Genetech, Seoul, Republic of Korea). Sanger sequencing was performed at Macrogen (Seoul,

183 Republic of Korea). The nucleotide sequences were analyzed using Lasergene's SeqMan

184 program.

185

\section{Genome walking from a PSY1-adjacent gene}

187 To reveal the structural variation of PSYI in MY, genome walking was performed starting 188 from PSYl-adjacent gene. Separate aliquots of MY gDNA were digested using four 189 restriction enzymes: DraI, EcoRV, PvuII, and StuI. Each digested DNA was separately ligated 190 to a genome walker adaptor of Universal GenomeWalker 2.0 kit (Takara Bio). After the 191 library construction, consecutive PCR amplifications were performed. For the primary PCR, an outer adaptor primer (AP1) and an outer gene-specific primer (GSP1) were used. The primary PCR product was diluted 50x and used as a template for the secondary PCR with a nested adaptor primer (AP2) and a nested gene-specific primer (GSP2). Capana04g002520 is located in the adjacent 5' region of PSY1 (Capana04g002519) based on the Zunla reference genome (v2.0), so gene-specific primers were first designed to target the coding region of Capana04g002520. The secondary PCR amplicons were purified and sequenced by Macrogen. The next set of gene-specific primers was subsequently designed based on the sequenced genomic region. The primary PCR conditions were as follows: eight cycles of $94^{\circ} \mathrm{C}$ for $25 \mathrm{~s}$ and $72^{\circ} \mathrm{C}$ for $3 \mathrm{~min}$, then 32 cycles of $94^{\circ} \mathrm{C}$ for $25 \mathrm{~s}$ and $67^{\circ} \mathrm{C}$ for $3 \mathrm{~min}$. The secondary PCR conditions were as follows: six cycles of $94^{\circ} \mathrm{C}$ for $25 \mathrm{~s}$ and $72^{\circ} \mathrm{C}$ for $3 \mathrm{~min}$, then 19 cycles of $94^{\circ} \mathrm{C}$ for $25 \mathrm{~s}$ and $67^{\circ} \mathrm{C}$ for $3 \mathrm{~min}$.

\section{Long-range PCR amplification of CCS}

205 To investigate whether an insertion was present in MY CCS, a long-range PCR was 206 performed using the primers for CCS amplification (Table 1) and PrimeSTAR GXL DNA 207 polymerase (Takara Bio). A two-step PCR was performed for 30 cycles of $98^{\circ} \mathrm{C}$ for $10 \mathrm{~s}$ and $20868^{\circ} \mathrm{C}$ for $10 \mathrm{~min}$. The resulting amplicons were purified and cloned into a modified T-blunt 209 vector (SolGent, Daejeon, Republic of Korea). The plasmid DNA was extracted using an 210 AccuPrep plasmid mini extraction kit (Bioneer, Daejeon, Republic of Korea) and sequenced 211 by Macrogen. 
213 Sequence-characterized amplified region (SCAR) marker development for the 214 structural variations of PSY1 and CCS

215 SCAR markers for PSY1 and CCS were designed based on the identified structural variations.

216 A common (COM) primer and an allele-specific primer for the MR or MY genotypes were

217 paired for gene amplification (Table S1). The SCAR markers were used to genotype the MY

$218 \times$ MR $F_{2}$ plants, and to screen germplasm accessions of interest which PSY1 was not

219 amplified in another study (Jeong et al., 2018). SCAR marker PCR condition was as follows:

22035 cycles of $98^{\circ} \mathrm{C}$ for $10 \mathrm{~s}, 60^{\circ} \mathrm{C}$ for $30 \mathrm{~s}$, and $72^{\circ} \mathrm{C}$ for $1 \mathrm{~min}$. The resulting amplicons were 221 separated on a $2 \%$ agarose gel.

\section{Expression analysis of PSY2 using quantitative real-time PCR (qRT-PCR)}

224 For the precise measurement of PSY2 expression, a qRT-PCR was carried out using a 225 LightCycler 480 system (Roche, Basel, Switzerland) using SYTO 9 stain (Thermo Fisher 226 Scientific). The reaction mixture comprised a total volume of $20 \mu \mathrm{L}$, containing $2 \mu \mathrm{L} 4 \times$ 227 diluted cDNA, $0.3 \mu \mathrm{L}$ R Taq (Takara Bio), $2 \mu \mathrm{L}$ 10× PCR buffer, $2 \mu \mathrm{L} 10 \mathrm{mM}$ dNTPs, $0.5 \mu \mathrm{L}$ $22810 \mathrm{pmol}$ primers, and $0.5 \mu \mathrm{L}$ SYTO 9. The primer sequences were as follows: 5'229 AGACAGAGGTGGAATTTTGGGTCT-3' (forward) and 5'230 CAAATTCCCCGGAAGCACA-3' (reverse). The real-time PCR involved 45 cycles of $95^{\circ} \mathrm{C}$ 231 for $10 \mathrm{~s}, 60^{\circ} \mathrm{C}$ for $20 \mathrm{~s}$, and $72^{\circ} \mathrm{C}$ for $20 \mathrm{~s}$. Three replicate reactions were performed. The 232 Actin served as an internal control.

Complementation assay for PSY2 in E. coli

235 To analyze the enzymatic activity of PSY2, a complementation assay was conducted using 236 pAC-85b (Addgene plasmid \#53282). pAC-85b is derived from pAC-BETA (Addgene 237 plasmid \#53272), which contains $C r t E, C r t Y, C r t I$, and $C r t B$ (the carotenogenic gene cluster) 238 from Erwinia herbicola for $\beta$-carotene production. pAC-85b lacks PSY homolog CrtB compared to pAC-BETA, meaning that $E$. coli transformed with $\mathrm{pAC}-85 \mathrm{~b}$ can only produce

242 For the transgenic expression of PSY1 and PSY2, pET-28a(+) (Novagen; Merck Millipore, 243 Burlington, USA) was used (Fig. S1). To construct pET-PSY1 and pET-PSY2, the full-length 244 cDNA fragments were amplified using the following primers with a 4-bp adapter and 6-bp 
restriction site (underlined): 5'-CACAGGATCCATGTCTGTTGCCTTGTTATGG-3' (PSY1 forward) and 5'-CACAGTCGACATCCTGATTTCATGTTCTTGTAGAAG-3' (PSY1 reverse); 5'-CCAAGGATCCATGTCTGTTGCTTTGTTGTGG-3' (PSY2 forward) and 5'GGAAGTCGACCAACTTCATTCATGTCTTTGTTAGTG-3' (PSY2 reverse). The amplicons were cloned into the BamHI and SalI sites of pET-28a(+). After the sequences were confirmed, pAC-85b and either pET-PSY1 or pET-PSY2 were co-transformed into the E. coli BL21(DE3) competent cells (TransGen), and named PC1 and EXP respectively. The control cells were co-transformed with pAC-85b and pET-28a(+) for negative control (NC), and with pAC-BETA for positive control (PC2) for a visual confirmation of the $\beta$-carotene content.

The transformed $E$. coli cells were grown overnight at $28^{\circ} \mathrm{C}$ in $2 \mathrm{~mL}$ of a Luria-Bertani (LB) liquid medium containing $50 \mathrm{mg} / \mathrm{mL}$ kanamycin and $35 \mathrm{mg} / \mathrm{mL}$ chloramphenicol and used to inoculate $10 \mathrm{~mL} \mathrm{LB}$ medium containing the same antibiotics. The cells were grown at $28^{\circ} \mathrm{C}$ to $\mathrm{OD}_{600} 0.5-0.7$, then $50 \mu \mathrm{M}$ isopropylthio- $\beta$-galactoside (IPTG) was added and the cells were further incubated in darkness at $16^{\circ} \mathrm{C}$ for $24 \mathrm{~h}$. Cell pellets were harvested by centrifugation and the colors of the pellets were analyzed.

\section{Immunoblot assay of the PSY proteins produced by the transgenic E. coli}

NC, EXP, and PC1 E. coli were grown at $16^{\circ} \mathrm{C}$ for $24 \mathrm{~h}$, after which $2 \mathrm{~mL}$ of each sample was transferred into $1.5-\mathrm{mL}$ tubes, harvested by centrifugation, and frozen at $-20^{\circ} \mathrm{C}$. The frozen cells were resuspended in $800 \mu \mathrm{L}$ distilled water and $200 \mu \mathrm{L} 5 \times$ sample buffer, then incubated at $98^{\circ} \mathrm{C}$ for $5 \mathrm{~min}$ for denaturation. The proteins were separated using SDS-PAGE at $130 \mathrm{~V}$ for $1 \mathrm{~h} 30 \mathrm{~min}$. After the electrophoresis, one repeat was cut from the gel and transferred to an Amersham Hybond $^{\mathrm{TM}}$-P membrane (GE Healthcare, Chicago, USA), using manufacturer's instructions. The other sample replicate was stained with Coomassie brilliant blue solution.

271 The membrane was blocked using TBST buffer containing 5\% BSA for $1 \mathrm{~h}$ at room temperature (RT). An antibody was raised against the middle region of the tomato PSY1 in mouse (anti-SIPSY1 (M)), as a primary antibody to bind to PSY2 for amino acid sequence similarity between SIPSY1 and CaPSY2. Anti-mouse-IgG-HRP was used as a secondary antibody. The anti-PSY1 (M) antibody ( $1 \mathrm{mg} / \mu \mathrm{L})$ was diluted 5000:1 using TBST buffer containing $5 \%$ BSA. The primary antibodies were applied to the blocked membrane, and 
incubated at RT overnight. The membranes were washed twice by shaking and twice on the rocker for 10 min with TBST buffer. The secondary antibody $(1 \mathrm{mg} / \mu \mathrm{L})$ was diluted 5000:1 with TBST buffer, and applied to the membrane for $3 \mathrm{~h}$ on rocker speed 1 . The membrane was washed as described above. Clarity ${ }^{\mathrm{TM}}$ Western ECL substrate (Bio-Rad) and Fusion FX (Vilber Lourmat, Collegien, France) were used for signal development and detection following the manufacturers' instructions. The expected PSY2 sizes were calculated using a protein molecular weight calculator (www.sciencegateway.org/tools/proteinmw.htm).

\section{Carotenoid extraction and UPLC analysis}

The carotenoids were extracted using methods specific to the materials (either fruit pericarp or E. coli). For the pericarp tissues, the carotenoid extraction and saponification were conducted as described by Kim et al. (2016). For the E. coli transformants, cell pellets were obtained using centrifugation, from which the carotenoids were extracted with $600 \mu \mathrm{L}$ HPLCgrade acetone (Honeywell, Charlotte, USA), as described by López-Emparán et al. (2014).

For the extracts derived from both the pericarps and E. coli cell pellets, the carotenoids were analyzed using an Acquity UPLC-H-Class system (Waters, Milford, MA, USA). The compounds were separated using an Acquity UPLC HSS T3 column $(2.1 \times 100,1.8 \mu \mathrm{m})$ at $35^{\circ} \mathrm{C}$. The mobile phase was a binary solvent system consisting of phase A (acetonitrile/methanol/methylene chloride, 65/25/10, v/v/v) and phase B (distilled water). The gradients were programmed according to the previously described method (Kim et al., 2016). For the qualitative and quantitative analyses, 11 carotenoid standards were purchased from Sigma-Aldrich (St. Louis, USA); antheraxanthin, capsanthin, capsorubin, lutein, neoxanthin, violaxanthin, zeaxanthin, $\alpha$-carotene, $\alpha$-cryptoxanthin, $\beta$-carotene, and $\beta$-cryptoxanthin.

\section{VIGS of PSY2 in MY}

Ligation independent cloning (LIC) was conducted for the construction of pTRV2-PSY2 as described by Kim et al. (2017). The partial coding sequence of PSY2 was amplified with the following primers containing 15-bp adapter sequences (underlined): 5'CGACGACAAGACCCTTGTTGCTTTGTTGTGGGTTG-3' (forward) and 5'GAGGAGAAGAGCCCTTCCCAAGTCCGAATATCTCAA-3' (reverse). The purified PCR product and PstI-digested pTRV2-LIC vector were treated with T4 DNA polymerase 
(Enzymatics, Beverly, USA) and $5 \times$ blue buffer in common, and $10 \mathrm{mM}$ dATP or dTTP respectively. Both mixtures were incubated at $22^{\circ} \mathrm{C}$ for $30 \mathrm{~min}$, then $75^{\circ} \mathrm{C}$ for $20 \mathrm{~min}$. A total of $30 \mathrm{ng}$ PCR product and $400 \mathrm{ng}$ TRV2-LIC vector were mixed and incubated at RT for 15 min. The mixture was transformed into E. coli DH5 $\alpha$ competent cells (TransGen). Plasmids were extracted, sequenced by Macrogen, and introduced into Agrobacterium tumefaciens strain GV3101 through electroporation at $2.0 \mathrm{kV}$. For the negative VIGS control, pTRV2-GFP was used. Both pTRV2-LIC and pTRV2-GFP vectors were kindly provided by Dr. Doil Choi, Seoul National University.

Agrobacterium carrying pTRV1, pTRV2-GFP, or pTRV2-PSY2 were grown overnight at $30^{\circ} \mathrm{C}$ in $\mathrm{LB}$ medium with $50 \mu \mathrm{g} / \mathrm{mL}$ rifampicin and kanamycin, then harvested using centrifugation. The cells were resuspended in $10 \mathrm{mM} \mathrm{MES,} 10 \mathrm{mM} \mathrm{MgCl}$, and $200 \mu \mathrm{M}$ acetosyringone to a final $\mathrm{OD}_{600}$ of $0.7-0.8$, and incubated in a rocking incubator at RT for $3 \mathrm{~h}$. Cell cultures containing pTRV1 and either of the pTRV2 constructs were mixed in a 1:1 ratio and infiltrated into the abaxial side of both pepper cotyledons. The inoculated plants were incubated at $16^{\circ} \mathrm{C}$ in the dark for one day, then grown at $25^{\circ} \mathrm{C}$ under a16-h/8-h light/dark photoperiod.

\section{Expression analysis of PSY2 in VIGS-treated fruit using RT-PCR}

Mature fruits were harvested from pTRV2-GFP- or pTRV2-PSY2-inoculated MY plants at four months after inoculation. Segments of the mature pericarp displaying lighter colors were using the following reaction mixture: $2 \mu \mathrm{L} 4 \times$ diluted cDNA, $0.3 \mu \mathrm{L}$ EX Taq (Takara, Japan), $2.5 \mu \mathrm{L} \mathrm{10 \times} \mathrm{PCR} \mathrm{buffer,} 2 \mu \mathrm{L} 10 \mathrm{mM}$ dNTPs, $0.5 \mu \mathrm{L} 10$ pmol primers, and $17.2 \mu \mathrm{L}$ triple distilled water. The same primers used to amplify the entire PSY2 gene were used (Table 1). The RT-PCR conditions were 28 cycles of $95^{\circ} \mathrm{C}$ for $30 \mathrm{~s}, 58^{\circ} \mathrm{C}$ for $30 \mathrm{~s}$, and $72^{\circ} \mathrm{C}$ for $90 \mathrm{~s}$.

335 Three biological replicates and the Actin were used for reproducibility and internal control, respectively.

\section{Carotenoid extraction and saponification of VIGS-treated fruits}

339 Carotenoids were extracted as described by Yoo et al. (2017), with some modifications and 340 under dim light. The samples were put on ice to prevent carotenoid oxidation and degradation. 
341 The lighter-colored pTRV2-PSY2-inoculated pericarps and the pTRV2-GFP-inoculated

342 pericarps were diced and freeze-dried. Pieces from two TRV2-PSY2-inoculated fruits were

343 pooled together to obtain enough tissue for carotenoid extraction.

The freeze-dried tissues were ground, and about $50 \mathrm{mg}$ of tissue powder was placed in a 2$\mathrm{mL}$ tube with two glass beads. For the saponification, $600 \mu \mathrm{L}$ tetrahydrofuran (THF), $375 \mu \mathrm{L}$ petroleum ether, and $150 \mu \mathrm{L} 25 \% \mathrm{NaCl}$ was added to the samples, vortexed, and centrifuged for $3 \mathrm{~min}$ at $1,500 \mathrm{~g}$ at $4^{\circ} \mathrm{C}$. The upper phase was transferred into a new 2 -mL tube. A $500-\mu \mathrm{L}$ aliquot of petroleum ether was added to the remaining sample, which were then centrifuged, and this second upper phase was combined with the first upper phase. The samples were then concentrated using vacuum concentrator. The dried samples were dissolved with $500 \mu \mathrm{L}$ HPLC-grade acetone (Honeywell) using sonication and filtered using a 0.2- $\mu \mathrm{m}$ syringe filter (Acrodisc LC $13 \mathrm{~mm}$ syringe filter, PVDF membrane; Pall, NY, USA) and bottled in a 1.5mL HPLC amber vial. The HPLC analysis of the carotenoids was performed by the NICEM chromatography lab (Seoul National University). Capsanthin, capsorubin, lutein, zeaxanthin, $\alpha$-carotene, $\beta$-carotene, and $\beta$-cryptoxanthin were used as standards.

\section{Results}

\section{MY harbors structural variations in PSY1 and CCS}

Two C. annuum accessions, MR and MY, were used to identify the genetic factors controlling the formation of yellow coloration in the mature pepper fruit. The seven carotenoid biosynthetic genes PSY1, PSY2, PSY3, Lcyb, CrtZ-2, ZEP, and CCS, were amplified from the gDNA using PCR to identify any differences between the two genotypes. The expected sizes of the amplicons are shown in Table 1. In both MR and MY, the expected amplicon sizes were obtained for PSY2, PSY3, Lcyb, CrtZ-2, and ZEP, and no sequence variations were discovered in these genes between the accessions. By contrast, no amplicons were obtained from MY for PSY1 and CCS (Fig. 2A). These results indicated the possible existence of structural variations in the PSYI and CCS genes in MY.

\section{MY has a complete deletion of PSY1 and a transposon insertion in CCS}

371 To identify the structural variation of PSYI in MY, various regions of the gene, including the 372 upstream and downstream sequences, were amplified using 12 sets of primers. No fragments 
373 of the expected size were obtained (data not shown), indicating the existence of a huge

374 insertion or a deletion in the gene. To reveal the structural variation in PSY1 in MY, genome

375 walking was performed. Since target-specific primers are required for genome walking, the

376 first primer set was designed using the gene Capana04g0025200, which is adjacent to PSYI.

377 Using several rounds of genome walking, a 19,948-bp deletion including the entire PSY1

378 genomic region was identified in the MY genome (Fig. 3A). To test commonality of this

379 mutation among $C$ annuum germplasm, we genotyped the 18 accessions showing yellow fruit

380 color (Jeong et al., 2019) using the SCAR marker (Table S1) and showed that 15 of them had

381 the same structural mutation as MY (Fig. S4).

To investigate the structural variation of CCS in MY, a long-range PCR was conducted.

Several regions of $C C S$ were amplified normally (data not shown), indicating the presence of limitation, the extension time of the PCR cycle was increased to $10 \mathrm{~min}$, resulting in the amplification of a sequence containing a 6,750-bp insertion located 1,339 nt along CCS in MY (Fig. 3B). When this amplicon was sequenced and analyzed, the inserted sequence was observed to contain a Ty1/Copia-like retrotransposon, almost 1-kb long-terminal repeat (LTR) sequences, and a 6-bp target site duplication sequence (TSD)(ACTGGC) (Fig. 3B).

\section{MY produces a transcriptional variant of $C C S$}

393 As MY contains the full CCS sequence, although interrupted by the transposon, an RT-PCR 394 was performed to test whether functional transcripts of CCS were present in these plants. In 395 MR, a 1,497-bp amplicon was obtained. By contrast, a much smaller amplicon (513 bp) was obtained from MY. A sequence analysis of this transcript showed that most of the transposon, along with $1 \mathrm{~kb}$ of $C C S$, were spliced out in MY (Fig. 3C). Such transcriptional variation might result from the provision of a conserved sequence in the splicing junction (5'-GT/AG$\left.3^{\prime}\right)$ by the inserted transposon sequence (Brown, 1986), which might be functioned as an active splicing junction of $C C S$. The resulting transcripts are expected to encode a truncated protein containing 115 amino acids, whereas functional CCS comprises 498 amino acids.

404 To test whether the structural variations of PSY1 and CCS could result in the yellow fruit 
405

color of MY, an inheritance study was performed using a segregating population derived from a cross between MR and MY. All fruits from the $F_{1}$ progeny were red, indicating that the red color is dominant over yellow. In the $\mathrm{F}_{2}$ population, red, orange, and yellow fruits showed a segregation ratio of 156:111:14 (Table 2). This ratio was consistent with an expected ratio of 9:6:1 $\left(\chi^{2}=1.26, P=0.59\right)$, suggesting that two genes epistatically interact to determine fruit color in this population.

To test whether PSY1 and CCS are involved in the determination of pepper fruit color, SCAR markers were used to genotype the $\mathrm{F}_{2}$ individuals (Fig. S2). Plants containing the wild-type alleles (PSY1/- and CCS/-) of both genes produced red fruits. By contrast, yellow fruits were produced by plants containing homozygous recessive alleles (psyl/psyl ccs/ccs) for both genes. In plants containing either the PSY1/- ccs/ccs or psyl/psyl CCS/- genotypes, the fruits were orange in color (Table 3).

\section{Orange pepper fruits have either PSY1 or CCS mutations}

No phenotypic differences were observed between the orange-colored fruits produced by plants with different genotypes (PSY1/- ccs/ccs or psyl/psyl CCS/-). Their carotenoid profiles were analyzed using UPLC. For each genotypic group, UPLC was performed with three biological replicates. The major carotenoid component of plants with the PSY1/-CCS/genotype was capsanthin, whereas the main carotenoid in the plants harboring psyl/psyl ccs/ccs were neoxanthin (Fig. 4). Two distinct differences were identified between the orange-colored fruits produced by plants containing the different genotypes. First, the total carotenoid contents of the fruits of the PSY1/- ccs/ccs genotype were four times higher than those of the fruits of the psyl/psyl CCS/- genotype. Second, both capsanthin and capsorubin, the typical red pigments present in red peppers, were almost undetectable $(0.35 \mathrm{mg} / 100 \mathrm{~g}$ dry weight (DW)) in the fruits of the PSY1/- ccs/ccs genotype, whereas these pigments accounted for almost $70 \%$ of total carotenoid levels in the psyl/psyl CCS/- orange fruits $(5.67 \mathrm{mg} / 100 \mathrm{~g}$ DW). These results indicated that, although the visible colors were similar between the two orange genotypes, the composition of pigments producing the orange color were different.

In the psyl knockout (psyl/psyl) plants, the carotenoids accumulated in the fruits regardless of the CCS genotype, although the total carotenoid content was about 10-fold lower than that 
437

438

439

440

of the plants containing functional a PSYI gene. In contrast to the PSY1/- ccs/ccs plants, the content of each carotenoid component was decreased in the psyl/psyl ccs/ccs genotype. A similar trend was also observed in the psyl/psyl CCS/- plants compared with the PSY1/$C C S$ - plants, and the levels of most carotenoids except antheraxanthin were decreased. In conclusion, despite the impaired PSY1 activity, the carotenoid composition of the psyl/psyl plants was similar to the wild-type plants, although their levels were reduced (Fig. 4). This implies that other genes, such as the PSY homologs, might supplement the function of PSY1, regardless of $C C S$.

\section{PSY2 is expressed in pepper fruits}

Based on the UPLC data, it was postulated that PSY2 or PSY3 might be involved in carotenoid biosynthesis in the pepper fruits. To test this hypothesis, the expression levels of the PSY homologs were analyzed in the mature fruit pericarps using RT-PCR. The PSY1 transcripts were only detected in MR. PSY2 transcripts of the expected size were obtained from both MR and MY, while PSY3 transcripts were not detected in either accession (Fig. 5A). These results demonstrate that $P S Y 2$ is expressed in pepper fruits and may be involved in color formation. A further analysis using qRT-PCR confirmed that PSY2 is expressed in the pericarp tissues, although the highest levels of expression were detected in the leaf tissues (Fig. 5B). The PSY2 expression levels in the leaves and fruits were significantly higher in MY than in MR, indicating that PSY2 may compensate for the loss of PSY1 function in MY.

\section{PSY2 has the same enzymatic function as PSY1}

The enzymatic function of PSY2 was tested using a complementation assay in E. coli BL21(DE3) cells carrying pAC-85b and pET-PSY2 (EXP). The same E. coli strain containing pAC-85b and pET-PSY1 was used as a positive control (PC1), while cells containing pAC$85 \mathrm{~b}$ and the empty pET-28a(+) vector were used as the negative control (NC). For the comparison of the colored pigments produced by these cells, transformants producing $\beta$ carotene (pAC-BETA) were also used (Fig. S1). If PSY2 is able to biosynthesize the carotenoid backbone, the E. coli pellets would be orange in color due to the resulting $\beta$ carotene content. As shown in Fig. 6A, the E. coli pellets from EXP were orange, as were those of the two positive control groups, PC1 and PC2. UPLC analysis of the E. coli extracts was conducted to validate that the orange color of the experimental cells expressing PSY2 
469

470

471

472

473

474

475

476

was due to the accumulation of $\beta$-carotene. A clear $\beta$-carotene peak was detected in all cells except the negative control group (Fig. 6B). The $\beta$-carotene contents were $1.57 \mathrm{mg} / 100 \mathrm{~g}$ and $2.23 \mathrm{mg} / 100 \mathrm{~g}$ fresh weight (FW) in the cells containing pET-PSY2 and pET-PSY1, respectively. These results demonstrate that PSY2 has a similar catalytic activity to PSY1 in carotenoid biosynthesis.

To validate the production of the PSY proteins in the E. coli cells, an immunoblot assay was conducted. A 2-mL aliquot of each cell culture was harvested, treated with SDS sample buffer, and ran on a $12 \%$ SDS-PAGE gel. One of the two replicated gels were stained with Coomassie blue. The EXP with pET-PSY2 and PC1 with pET-PSY1 specific band sizes were between $38 \mathrm{kDa}$ and $52 \mathrm{kDa}$, as indicated in protein marker (Fig. 6C). The other sample replicate was transferred onto a nitrocellulose membrane and treated with an antibody against tomato SlPSY1 (Fig. S3), which showed a high amino acid sequence similarity with $C a P S Y 1$ (90.66\%) and CaPSY2 (82.96\%; data not shown). Specific bands of around $48 \mathrm{kDa}$ were detected in both EXP and PC1. The EXP band were slightly bigger than that of PC1, consistent with the expected sizes of CaPSY2 and CaPSY1, $48.44 \mathrm{kDa}$ and $47.07 \mathrm{kDa}$, respectively (Fig. 6C). These results demonstrate that the recombinant proteins are expressed in E. coli.

\section{Silencing of PSY2 leads to lighter yellow fruit color}

The function of PSY2 was evaluated in MY plants using TRV-mediated VIGS, while Agrobacterium cells carrying pTRV2-GFP were used as a negative control. The symptoms of PSY2 silencing were visualized at 15 days after inoculation (DAI). The pTRV2-GFPinoculated plants did not display any significant differences to the wild type. The PSY2silenced plants had a mosaic phenotype of pale and green patches on the leaves, due to the characteristics of the TRV vector (Fig. 7A). The flowers and fruits developed at about 60 and 75 DAI, respectively. There were no visible changes in the flower colors of both groups, but a slightly lighter peduncle color was observed in the TRV2-PSY2-inoculated plants (data not shown). In the pTRV2-GFP-inoculated plants, the immature fruits were a dark green color, whereas the immature fruits in the PSY2-silenced plants were white to pale green. The mature fruit color also showed a similar trend, as the pTRV2-GFP inoculated fruits showed an intense yellow color, whereas the PSY2-silenced fruits were white to ivory in color (Fig. 7B). 
502 RT-PCR was conducted to compare the expression levels of PSY2 in the mature fruits of the 503 pTRV2-GFP-inoculated and PSY2-silenced plants. While the fruits of the pTRV2-GFP504 inoculated plants expressed PSY2, there was almost no detectable PSY2 expression in the 505 PSY2-silenced fruit tissues, indicating the successful post-transcriptional gene silencing 506 (PTGS) of the target gene (Fig. 7C).

HPLC analysis was conducted for a quantitative and qualitative analysis of the carotenoid contents in the TRV-GFP- and TRV2-PSY2-inoculated mature fruits. The total carotenoid contents of TRV2-GFP and TRV2-PSY2 were $1.94 \mathrm{mg} / 100 \mathrm{~g}$ DW and $0.38 \mathrm{mg} / 100 \mathrm{~g} \mathrm{DW}$, respectively. The mature fruits of the control plants had a more than five-fold higher carotenoid content than the PSY2-silenced fruits. Lutein was detected as the most prominent component in both TRV2-GFP and TRV2-PSY2 (Fig. 7D and Fig. S5).

\section{Discussion}

517 In this study, we revealed that the MY pepper line, which produces yellow mature fruits, has 518 structural mutations in PSY1 and CCS. The yellow fruit color resulted from mutation of CCS 519 coding region in pepper was previously reported in various studies (Lefebvre et al., 1998; Popovsky and Paran 2000; Li et al., 2013). Our study also showed mutation in CCS coding region which resulted in transcriptional variant of 115 amino acids. Splicing variations and mutations in the coding sequence of PSY1 have been analyzed previously (Kim et al., 2010; Jeong et al., 2018); by contrast, we have reported the complete deletion of PSY1 for the first time. If PSY1 were the only enzyme able to catalyze the first step of carotenoids biosynthesis, the psyl knockout plants would not be able to produce carotenoids; however, we detected low levels of carotenoids in the psyl knockout plants. PSY2 was expressed in the pericarp tissues of both the wild-type and psyl knockout plants, and we verified the enzymatic activity of PSY2 using a color complementation assay. A VIGS analysis also showed that the knockdown of PSY2 resulted in a lighter yellow color of mature fruits of psy1 mutant pepper. In conclusion, we showed that PSY2 controls the yellow fruit color in pepper psy1 knockout mutants. 
533 Tomato has three SIPSY genes, SIPSY1, SIPSY2, and SIPSY3 (Fantini et al., 2013). In contrast

534 to SlPSY1, which is expressed predominantly in fruit, SIPSY2 is expressed mainly in petals, 535 followed by the leaf, sepal, and ovary tissues, as well as at a lower level in the remaining 536 tissues, including the root and fruit (Giorio et al., 2008). SIPSY3 is expressed mainly in root 537 tissues under stress conditions (Kachanovsky et al., 2012). The silencing of SlPSY2 and 538 SlPSY3 did not result in dramatic differences in the mature tomato fruit color (Fantini et al., 539 2013), suggesting that these genes have a negligible role in the pericarp tissues. In addition to 540 CaPSY1, the pepper genome contains two more putative PSY genes, whose functions have 541 not yet been identified. We hypothesized that CaPSY2 might be involved in color formation 542 in MY as CaPSY3 was not amplified in MY fruit. Consistent with the expression pattern of 543 SIPSY2, only a basal level of CaPSY2 transcripts were obtained in the fruit, regardless of the 544 developmental stage analyzed (Fig. 5B). Meanwhile, the CaPSY2 transcript level was much 545 higher in MY than in MR in most tissues, indicating the positive feedback and corresponding 546 upregulation of this gene in MY due to the absence of CaPSY1. We revealed the enzymatic 547 activity of $\mathrm{CaPSY} 2$ using a color complementation assay in E. coli. Similar to previous 548 studies using pAC-85b to confirm the activity of $P S Y$ homologs in other crops, we first 549 investigated the color change of the cell pellet and performed an UPLC analysis of the cell 550 extract. Both results demonstrated that $\mathrm{CaPSY} 2$ functions as an enzyme in carotenoid 551 biosynthesis, and we concluded that CaPSY2 can supplement the activity of CaPSY1 and contribute to the development of the yellow color in MY fruits.

Using single-molecule real-time (SMRT) sequencing, Jeong et al. (2018) identified the sequence variations of six carotenoid biosynthetic genes, including PSY1 and PSY2, in diverse Capsicum genotypes. Of the 94 C. annuum accessions they analyzed, PSY1 was not amplified from 18 lines. We hypothesized that these genotypes could have a structural variation identical to the large deletion revealed in the present study. The same deletion of PSY1 was found in 15 out of 18 accessions that previously did not showed PSY1 amplification using SCAR marker designed in this study (Fig. S4). The marker developed in this study is therefore widely applicable for use in other $C$. annuum germplasms. Moreover, Jeong et al. (2018) reported another three psyl knockout mutations in eight accessions, two of which are frame-shift mutations (psyl-c5 and psyl-c10) and the other is a nonsense mutation (psy1-c9). There were, however, no critical mutations identified in PSY2. These 
results also support our hypothesis that PSY2 may complement the function of PSY1 in nonfunctional $P S Y 1$ accessions.

According to the three-locus model, the diverse colors of pepper fruits are determined by PSY1, CCS, and one unidentified locus (Lefebvre et al., 1998; Huh et al., 2001). It is not possible to state that PSY2 is encoded by the last locus based solely on the results of our study, as we have not found the natural PSY2 mutation with mutant PSY1. Today, other aspects of carotenoid metabolism have been investigated for their role in fruit colors of pepper. In these studies, several transcription factors have been revealed to play a role in the color intensities of mature pepper fruits. The Golden2-like transcription factor (GLK2) and Arabidopsis pseudo response regulator 2-like (APRR2) affect plastid levels and thus regulate color in a quantitative manner in pepper fruit (Brand et al., 2012; Pan et al., 2013). To obtain clear evidence of the function of PSY2 in fruit color formation, further experiments were required. For this reason, we used VIGS to silence PSY2 expression in the psyl knockout plants, which resulted in a white mosaic phenotype in both the leaves and fruit, supporting the other results obtained in this study.

Using an UPLC analysis, we analyzed the carotenoid profiles of two pepper genotypes producing orange fruits. The orange color of the PSYI/- ccs/ccs fruits resulted from the moderate accumulation of diverse carotenoid components except capsanthin and capsorubin, whereas the orange color of psyl/psyl CCS/- fruits was generated by the proportionally high level of red pigments (52.0\% for capsanthin, $18.9 \%$ for capsorubin), although their absolute contents are considerably lower than that of the PSY1/- CCS/- type. In the case of PSY1/$C C S /$ - red fruits, the proportion of these red pigments accounts for $67.5 \%$ of all carotenoids, which was slightly less than that of the pigments in the psyl/psyl CCS/- orange fruits. This

590 implies that the absolute content of the carotenoid pigments is more important for the 591 development of red fruits than the relative proportions of red and other pigments.

In conclusion, we demonstrated that a candidate gene approach combined with chemotyping via UPLC can be a useful tool for the identification of genetic factors controlling the carotenoid metabolic pathway. While the contribution of PSY2 seemed to be minimal in pepper fruit compared with that of functional PSY1, PSY2 seems to play an essential role in 
bioRxiv preprint doi: https://doi.org/10 1101/797977; this version posted October 8,2019 . The copyright holder for this preprint (which was not certified by peer review) is the author/funder, who has granted bioRxiv a license to display the preprint in perpetuity. It is made available under aCC-BY-NC-ND 4.0 International license.

Functional analysis of Phytoene synthase 2 in pepper fruit

597 the psyl knockout individuals, as it can allow a basal level of carotenoid accumulation. PSY2

598 must therefore be considered alongside PSY1 and CCS as an essential gene for the successful

599 breeding of peppers with new color and carotenoid profiles. 


\section{Supplementary data}

601 Table S1. List of primers used in the PSYI and CCS SCAR marker analyses.

602 Fig. S1. Vector information used in the color complementation assay.

603 Fig. S2. SCAR marker genotyping of PSY1 and CCS.

604 Fig. S3. Amino acid sequence alignment of pepper and tomato PSY1 and PSY2.

605 Fig. S4. SCAR marker test of accessions from which PSY1 could not be amplified.

606 Fig. S5. HPLC profiles of the carotenoid extracts obtained from the PSY2 VIGS-treated MY

607 plants.

608 


\section{Acknowledgments}

610 This work was supported by the Korea Institute of Planning and Evaluation for Technology in

611 Food, Agriculture, and Forestry (IPET) through the Agriculture, Food, and Rural Affairs

612 Research Center Support Program (Vegetable Breeding Research Center, 710011-03), funded

613 by the Ministry of Agriculture, Food, and Rural Affairs (MAFRA). This work was carried out

614 with the support of the Cooperative Research Program for Agriculture Science \& Technology

615 Development (Project No. PJ01322901), Rural Development Administration, Republic of 616 Korea. 


\section{References}

Al-Babili S, Bouwmeester HJ. 2015. Strigolactones, a novel carotenoid-derived plant hormone. Annual Review of Plant Biology 66, 161-186.

Blas AL, Ming R, Liu Z, Veatch OJ, Paull RE, Moore PH, Yu Q. 2010. Cloning of the papaya chromoplast-specific lycopene beta-cyclase, $C p C Y C-b$, controlling fruit flesh color reveals conserved microsynteny and a recombination hot spot. Plant Physiology 152, 20132022.

Borovsky Y, Tadmor Y, Bar E, Meir A, Lewinsohn E, Paran I. 2013. Induced mutation in $\beta$-CAROTENE HYDROXYLASE results in accumulation of $\beta$-carotene and conversion of red to orange color in pepper fruit. Theoretical and Applied Genetics 126, 557-565.

Bouvier F, Hugueney P, d'harlingue A, Kuntz M, Camara B. 1994. Xanthophyll biosynthesis in chromoplasts: Isolation and molecular cloning of an enzyme catalyzing the conversion of 5, 6ロepoxycarotenoid into ketocarotenoid. The Plant Journal 6, 45-54.

Brand A, Borovsky Y, Meir S, Rogachev I, Aharoni A, Paran I. 2012. pc8.1, a major QTL for pigment content in pepper fruit, is associated with variation in plastid compartment size. Planta 235, 579-588.

Brown JWS. 1986. A catalogue of splice junction and putative branch point sequences from plant introns. Nucleic Acids Research 14, 9549-9559.

Cunningham FX Jr, Gantt E. 2007. A portfolio of plasmids for identification and analysis of carotenoid pathway enzymes: Adonis aestivalis as a case study. Photosynthesis Research 92, 245-259.

Cunningham FX Jr, Pogson B, Sun Z, McDonald KA, DellaPenna D, Gantt E. 1996. Functional analysis of the beta and epsilon lycopene cyclase enzymes of Arabidopsis reveals a mechanism for control of cyclic carotenoid formation. Plant Cell 8, 1613-1626. 
Domonkos I, Kis M, Gombos Z, Ughy B. 2013. Carotenoids, versatile components of oxygenic photosynthesis. Progress in Lipid Research 52, 539-561.

Fantini E, Falcone G, Frusciante S, Gillberto L, Giuliano G. 2013. Dissection of tomato lycopene biosynthesis through Virus-Induced Gene Silencing. Plant Physiology 163, 986-998.

Fraser PD, Bramley PM. 2004. The biosynthesis and nutritional uses of carotenoids. Progress in Lipid Research 43, 228-265.

Fu X, Feng C, Wang C, Yin X, Lu P, Grierson D, Xu C, Chen K. 2014. Involvement of multiple phytoene synthase genes in tissue and cultivar-specific accumulation of carotenoids in loquat. Journal of Experimental Botany 65, 4679-4689.

Giorio G, Stigliani AL, D’Ambrosio C. 2007. Phytoene synthase genes in tomato (Solanum lycopersicum L.)-new data on the structures, the deduced amino acid sequences and the expression patterns. The FEBS Journal 275, 527-535.

Guzman I, Hamby S, Romero J, Bosland PW, O'connell MA. 2010. Variability of carotenoid biosynthesis in orange colored Capsicum spp. Plant Science 179, 49-59.

Ha SH, Kim JB, Park JS, Lee SW, Cho KJ. 2007. A comparison of the carotenoid accumulation in Capsicum varieties that show different ripening colours: deletion of the capsanthin-capsorubin synthase gene is not a prerequisite for the formation of a yellow pepper. Journal of Experimental Botany 58, 3135-3144.

Huh JH, Kang BC, Nahm SH, Kim S, Ha KS, Lee MH, Kim BD. 2001. A candidate gene approach identified phytoene synthase as the locus for mature fruit color in red pepper (Capsicum spp.). Theoretical and Applied Genetics 102, 524-530.

Hurtado-Hernandez H, Smith PG. 1985. Inheritance of mature fruit color in Capsicum annuиm L. Journal of Heredity 76, 211-213. 
Jackson H, Braun CL, Ernst H. 2008. The chemistry of novel xanthophyll carotenoids. The American Journal of Cardiology 101, S50-S57.

Jeong HB, Kang MY, Jung A, Han K, Lee JH, Jo J, Lee HY, An JW, Kim S, Kang BC. 2018. Single-molecule real time sequencing reveals diverse allelic variations in carotenoid biosynthetic genes in pepper (Capsicum spp.). Plant Biotechnology Journal, doi: 10.1111.

Kachanovsky DE, Filler S, Isaacson T, Hirschberg J. 2012. Epistasis in tomato color mutations involves regulation of phytoene synthase 1 expression by cis-carotenoids. Proceedings of the National Academy of Sciences of the United States of America 109, 19021-19026.

Kang B, Gu Q, Tian P, Xiao L, Cao H, Yang W. 2014. A chimeric transcript containing Psyl and a potential mRNA is associated with yellow flesh color in tomato accession PI 114490. Planta 5, 1011-1021.

Kim J, Park M, Jeong ES, Lee JM, Choi D. 2017. Harnessing anthocyanin-rich fruit: a visible reporter for tracing virus-induced gene silencing in pepper fruit. Plant Methods 13, 3.

Kim JS, An CG, Park JS, Lim YP, Kim S. 2016. Carotenoid profiling from 27 types of paprika (Capsicum annuum L.) with different colors, shapes, and cultivation methods. Food Chemistry 201, 64-71.

Kim OR, Cho MC, Kim BD, Huh JH. 2010. A splicing mutation in the gene encoding phytoene synthase causes orange coloration in Habanero pepper fruits. Molecules and Cells 30, 569-574.

Kim YK, Kim S, Um JH, et al. 2013. Functional implication of $\beta$-carotene hydroxylases in soybean nodulation. Plant physiology 162, 1420-1433.

Lefebvre V, Kuntz M, Camara B, Palloix A. 1998. The capsanthin-capsorubin synthase gene: a candidate gene for the $y$ locus controlling the red fruit colour in pepper. Plant 
Molecular Biology 36, 785-789.

Li Z, Wang S, Gui XL, Chang XB, Gong ZH. 2013. A further analysis of the relationship between yellow ripe-fruit color and the capsanthin-capsorubin synthase gene in pepper (Capsicum sp.) indicated a new mutant variant in C. annuum and a tandem repeat structure in promoter region. PLoS One 8, e61996.

\section{López-Emparán A, Quezada-Martinez D, Zúñiga-Bustos M, Cifuentes V, Iñiguez-Luy}

F, Federico ML. 2014. Functional analysis of the Brassica napus L. phytoene synthase (PSY) gene family. PLoS One 15, e114878.

Nambara E, Marion-Poll A. 2005. Abscisic acid biosynthesis and catabolism. Annual Review of Plant Biology 56, 165-185.

Pan Y, Bradley G, Pyke K, et al. 2013 Network inference analysis identifies an APRR2-Like gene linked to pigment accumulation in tomato and pepper fruits. Plant Physiology 161, $1476-1485$.

Paran I, van der Knaap E. 2007. Genetic and molecular regulation of fruit and plant domestication traits in tomato and pepper. Journal of Experimental Botany 58, 3841-3852.

Perry KL, Simonitch TA, Harrison-Lavoie KJ, Liu ST. 1986. Cloning and regulation of Erwinia herbicola pigment genes. Journal of Bacteriology 168, 607-612.

Popovsky S, Paran I. 2000. Molecular genetics of the $y$ locus in pepper: its relation to capsanthin-capsorubin synthase and to fruit color. Theoretical and Applied Genetics 101, 8689.

Porebski S, Bailey LG, Baum BR. 1997. Modification of a CTAB DNA extraction protocol for plants containing high polysaccharide and polyphenol components. Plant Molecular Biology Reporter 15, 8-15. 
Rodríguez-Suárez C, Atienza SG, Pistón F. 2011. Allelic variation, alternative splicing and expression analysis of Psyl gene in Hordeum chilense Roem. et Schult. PLoS One 6, e19885.

Sun T, Yuan H, Cao H, Yazdani M, Tadmor Y, Li L. 2018. Carotenoid metabolism in plants: the role of plastids. Molecular Plant 11, 58-74.

Tian SL, Li L, Chai WG, Shah SN, Gong ZH. 2014. Effects of silencing key genes in the capsanthin biosynthetic pathway on fruit color of detached pepper fruits. BMC Plant Biology 14, 314 .

Wang H, Ou C, Zhuang F, Ma Z. 2014. The dual role of phytoene syntehase genes in carotenogenesis in carrot roots and leaves. Molecular Breeding : New Strategies in Plant Improvement 34, 2065-2079

Yoo H, Park W, Lee GM, Oh CS, Yeam I, Won DC, Kim CK, Lee J. 2017. Inferring the genetic determinants of fruit colors in tomato by carotenoid profiling. Molecules 22, 764.

Yuan H, Zhang J, Nageswaran D, Li L. 2015. Carotenoid metabolism and regulation in horticultural crops. Horticulture Research 2, 15036. 


\section{Tables}

Table 1. List of primers used to amplify the carotenoid biosynthetic genes.

\begin{tabular}{|c|c|c|c|c|}
\hline Gene & Gene no. & gDNA (bp) & CDS (bp) & Primer sequence ( $5^{\prime}$ to $3^{\prime}$ ) \\
\hline \multirow{2}{*}{ PSY1 } & \multirow{2}{*}{$\mathrm{CA} 04 \mathrm{~g} 04080$} & \multirow{2}{*}{2,844} & \multirow{2}{*}{1,260} & F: ATGTCTGTTGCCTTGTTATGG \\
\hline & & & & R: ATCCTGATTTCATGTTCTTGTAGAAG \\
\hline \multirow{2}{*}{$P S Y 2$} & \multirow{2}{*}{ CA02g20350 } & \multirow{2}{*}{2,985} & \multirow{2}{*}{1,299} & F: ATGTCTGTTGCTTTGTTGTGG \\
\hline & & & & R: CAACTTCATTCATGTCTTTGTTAGTG \\
\hline \multirow{2}{*}{$P S Y 3$} & \multirow{2}{*}{ CA01g12040 } & \multirow{2}{*}{2,599} & \multirow{2}{*}{1,078} & F: ATGCAGAAGAAAGTTACTAATAAGAGC \\
\hline & & & & R: CTATTGAATGGCCAAACTTGG \\
\hline \multirow{2}{*}{$L c y b$} & \multirow{2}{*}{ CA05g00080 } & \multirow{2}{*}{1,497} & \multirow{2}{*}{1,497} & F: ATGGATACGCTCTTGAGAACC \\
\hline & & & & R: TCATTCTTTATCCTGTAACAAATTG \\
\hline \multirow{2}{*}{ CrtZ-2 } & \multirow{2}{*}{ CA03g25820 } & \multirow{2}{*}{2,025} & \multirow{2}{*}{948} & F: ATGGCTGCTGAAATTTCAAT \\
\hline & & & & R: CTTTGATCATAATCTCTTCGAAC \\
\hline \multirow{2}{*}{$Z E P$} & \multirow{2}{*}{ CA02g10990 } & \multirow{2}{*}{4,802} & \multirow{2}{*}{1,986} & F: ATGTATTCAACTGTGTTTTACAC \\
\hline & & & & R: TTATGCTGTCCCCACGACTTT \\
\hline \multirow{2}{*}{$C C S$} & \multirow{2}{*}{ CA06g22860 } & \multirow{2}{*}{1,497} & \multirow{2}{*}{1,497} & F: ATGGAAACCCTTCTAAAGCCT \\
\hline & & & & R: TCAAAGGCTCTCTATTGCTAG \\
\hline
\end{tabular}


bioRxiv preprint doi: $\mathrm{https}$ //doi org/10.1101/797977; this version posted October 8,2019 . The copyright holder for this preprint (which was not certified by peer review) is the author/funder, who has granted bioRxiv a license to display the preprint in perpetuity. It is made available under aCC-BY-NC-ND 4.0 International license.

Functional analysis of Phytoene synthase 2 in pepper fruit

Table 2. Segregation of phenotypes in the $\mathrm{MR} \times \mathrm{MY} \mathrm{F}_{2}$ population.

\begin{tabular}{|c|c|c|c|c|c|c|}
\hline \multirow{2}{*}{ Population } & \multirow{2}{*}{$\begin{array}{l}\text { Total } \\
\text { plants }\end{array}$} & \multicolumn{3}{|c|}{ Mature fruit } & \multirow{2}{*}{ Expected ratio } & \multirow{2}{*}{$\chi^{2}$} \\
\hline & & Red & Orange & Yellow & & \\
\hline $\mathrm{MR} \times \mathrm{MY} \mathrm{F}_{2}$ & 281 & 156 & 111 & 14 & $9: 6: 1$ & 1.26 \\
\hline
\end{tabular}


bioRxiv preprint doi: https://doi org/10.1101/797977; this version posted October 8,2019 . The copyright holder for this preprint (which was not certified by peer review) is the author/funder, who has granted bioRxiv a license to display the preprint in perpetuity. It is made available under aCC-BY-NC-ND 4.0 International license.

\footnotetext{
Functional analysis of Phytoene synthase 2 in pepper fruit
}

Table 3. Co-segregation of genotypes and phenotypes in the $\mathrm{MR} \times \mathrm{MY} \mathrm{F}_{2}$ population.

\begin{tabular}{|c|c|c|c|c|c|c|c|}
\hline & & Red & Orange & Orange & Yellow & & \\
\hline Population & Size & $\begin{array}{l}P S Y 1 /- \\
C C S /-\end{array}$ & $\begin{array}{l}\text { PSY1/- } \\
\text { ccs/ccs }\end{array}$ & $\begin{array}{c}p s y 1 / p s y 1 \\
C C S /-\end{array}$ & $\begin{array}{c}p s y 1 / p s y 1 \\
c c s / c c s\end{array}$ & Expected ratio & $\chi^{2}$ \\
\hline $\mathrm{MR} \times \mathrm{MY} \mathrm{F}_{2}$ & 281 & 156 & 48 & 63 & 14 & $9: 3: 3: 1$ & 3.27 \\
\hline
\end{tabular}




\section{Figure legends}

Fig. 1. Mature pepper fruits of the genotypes used in this study. Mature fruit color of MicroPep Red (MR; A), MicroPep Yellow (MY; B), and an $\mathrm{F}_{1}$ hybrid derived from the MR $\times$ MY cross (C).

Fig. 2. Polymorphism survey of the carotenoid biosynthetic genes. (A) gDNA amplification of six carotenoid biosynthetic genes using PCR. Primers were design to amplify the full length of each gene. From the two genotypes, the expected amplicon sizes were obtained for PSY2, Lcyb, CrtZ-2, and ZEP. No amplicon was obtained for PSY1 and CCS in MY. (B) gDNA PCR amplification of the PSY genes. A difference in the amplification pattern between MY and MR was only detected for PSY1, for which no amplicon was obtained from MY.

Fig. 3. Structural variations of $P S Y 1$ and CCS in MY. (A) An almost 20-kb deletion spanning the PSY1 genomic region, revealed using genome walking from Capana04g002520. The deleted region is indicated with the diagonal lines. The primer used for the first genome walking run is indicated with a red arrow. (B) An almost 7-kb Ty1/Copia-like retrotransposon insertion was discovered 1,339 nt along CCS in MY. LTR, long terminal repeat. TSD, target site duplication. (C) Transcriptional variant of $C C S$ in MY. Compared with the full $C C S$ sequence in MR, much smaller bands were amplified from MY using RT-PCR. Such transcriptional variation was regarded as being caused by the provision of a conserved sequence in the splicing junction by the inserted sequence. The red letters represent the conserved sequences of the exon-intron junction. The genomic region indicated with a solid line denotes the region which is spliced out during transcription.

Fig. 4. Carotenoid profiles of each $F_{2}$ genotype. Among the 11 investigated carotenoid components, only the major carotenoids are described separately (capsanthin-capsorubin, zeaxanthin, $\alpha$-cryptoxanthin, and neoxnathin), with the remaining minor carotenoids grouped together.

Fig. 5. Expression pattern of the $P S Y$ genes in various tissues. (A) Expression analyses of the three PSY genes in the mature fruit pericarps. Actin serves as a control. (B) Expression analysis of PSY2 in various tissues. Relative transcript levels of PSY2 were determined using 
qRT-PCR, and normalized to the expression of Actin. The data are the means \pm SD of three independent experiments. S, fruit developmental stage.

Fig. 6. Complementation assay for PSY2 in E. coli. (A) Expression of PSY2 or PSY1 in E. coli strains carrying pAC-85b. An E. coli strain carrying the empty vector alone served as a negative control. A $\beta$-carotene-accumulating E. coli strain served as a positive control for the color formation. (B) UPLC analysis of carotenoids extracted from each experimental group. The $\beta$-carotene peak is indicated with an asterisk. Au, absorbance units. STD, standard mixture of $\alpha$ - and $\beta$-carotenes. (C) Western blot analysis of $P S Y$ expression in transformed $E$. coli. Coomassie-stained SDS-PAGE gel (left) and the Western blot analysis (right) of the negative control (NC), the experimental group (EXP), and the positive control (PC1) using the anti-PSY-antibodies. The EXP and PC1-specific bands are indicated by arrowheads.

Fig. 7. VIGS of PSY2 in MY. (A) Phenotypes of TRV2-GFP-inoculated MY (top) and TRV2PSY2-inoculated MY (bottom) plants at 60 days after inoculation (DAI). (B) Effect of the VIGS of PSY2 on the color of immature $(\mathrm{a}, \mathrm{b})$ and mature $(\mathrm{c}, \mathrm{d})$ fruit. TRV2-GFP-inoculated fruits (a, c) and TRV2-PSY2-inoculated fruits (b, d). Scale bar indicates $5 \mathrm{~mm}$. (C) Expression analysis of PSY2 using RT-PCR. Three biological replicates of PSY2-silenced fruits were used. Actin serves as a control. (D) Total carotenoid contents of TRV2-GFP- or TRV2-PSY2-inoculated MY fruits. The asterisk indicates a significant difference $(P<0.01)$ from the control, determined using a Student's $t$-test. TRV2-GFP was used as a vector control. 
bioRxiv preprint doi: https://doi.org/10.1101/797977; this version posted October 8, 2019. The copyright holder for this preprint (which was not certified by peer review) is the author/funder, who has granted bioRxiv a license to display the preprint in perpetuity. It is made available under aCC-BY-NC-ND 4.0 International license.

Functional analysis of Phytoene synthase 2 in pepper fruit

\section{Figures}

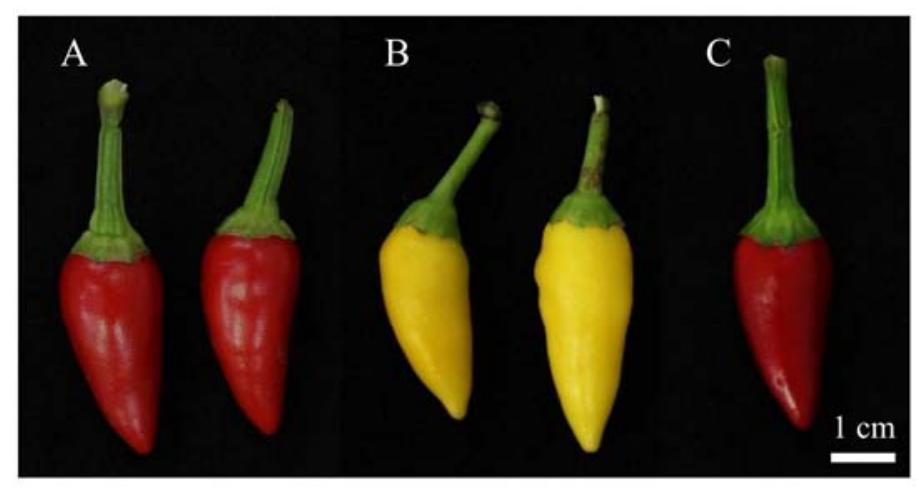

Fig. 1. Mature pepper fruits of the genotypes used in this study. 
bioRxiv preprint doi: https://doi.org/10.1101/797977; this version posted October 8, 2019. The copyright holder for this preprint (which was not certified by peer review) is the author/funder, who has granted bioRxiv a license to display the preprint in perpetuity. It is made available under aCC-BY-NC-ND 4.0 International license.
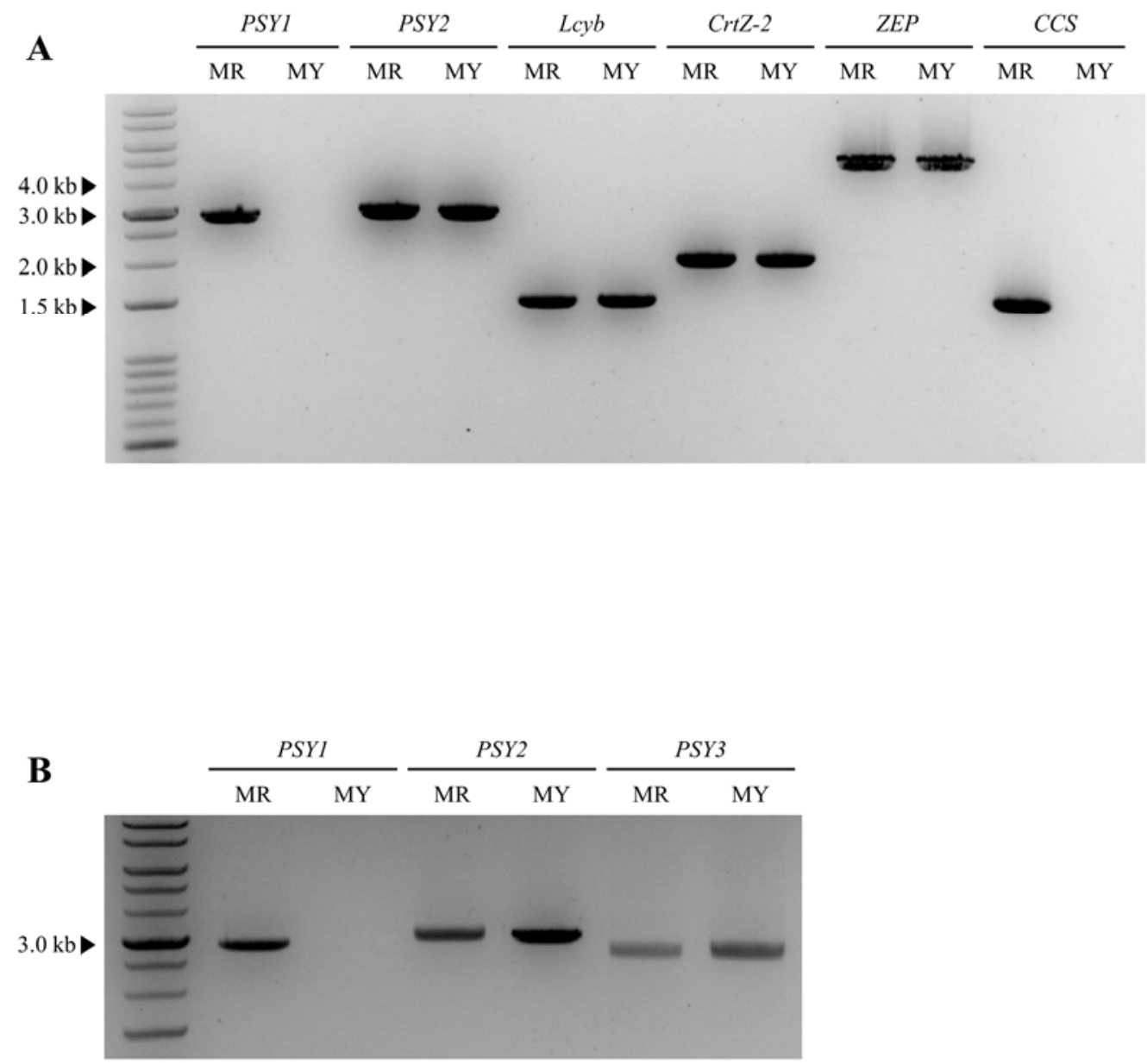

Fig. 2. Polymorphism survey of the carotenoid biosynthetic genes. 
bioRxiv preprint doi: https://doi.org/10.1101/797977; this version posted October 8 2019. The copyright holder for this preprint (which was not certified by peer review) is the author/funder, who has granted bioRxiv a license to display the preprint in perpetuity. It is made available under aCC-BY-NC-ND 4.0 International license.

A

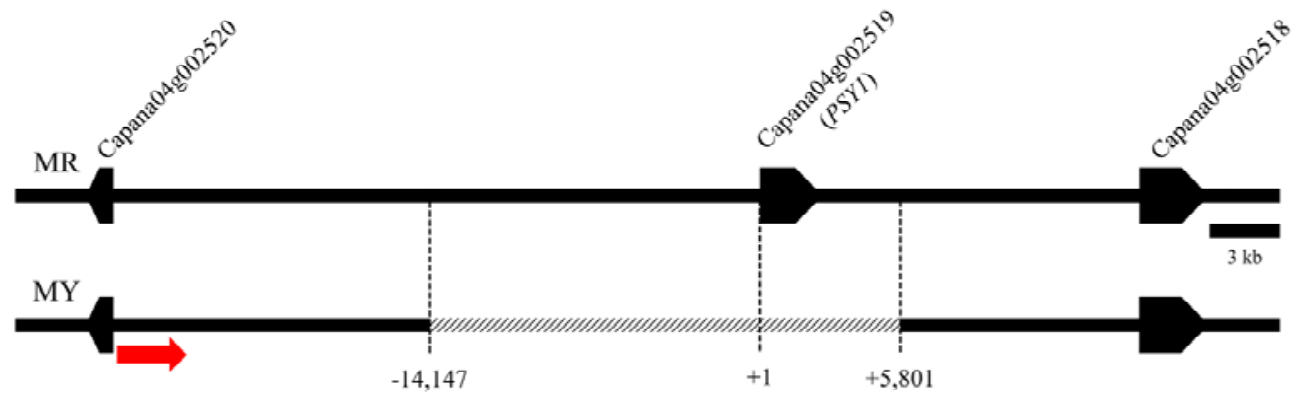

B

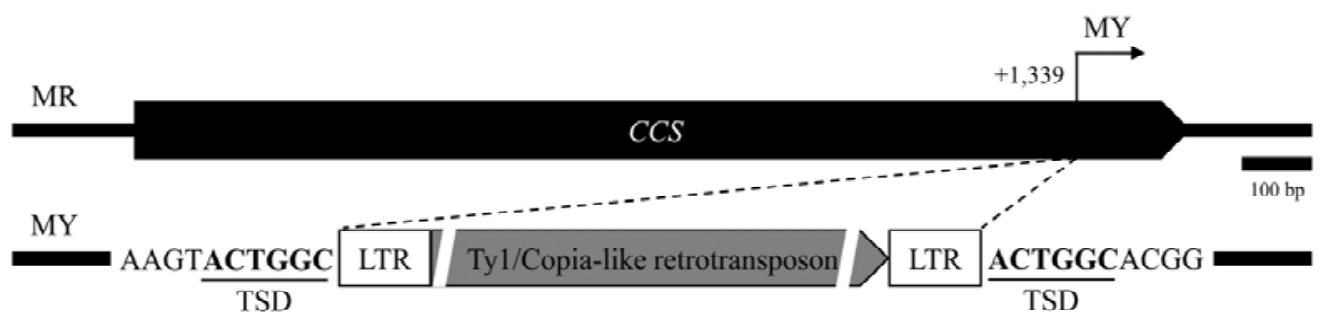

C

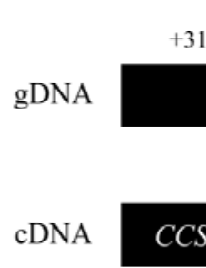

Fig. 3. Polymorphism survey of the carotenoid biosynthetic genes. 
bioRxiv preprint doi: https://doi.org/10.1101/797977; this version posted October 8, 2019. The copyright holder for this preprint (which was not certified by peer review) is the author/funder, who has granted bioRxiv a license to display the preprint in perpetuity. It is made available under aCC-BY-NC-ND 4.0 International license.

$$
\text { Functional analysis of Phytoene synthase } 2 \text { in pepper fruit }
$$

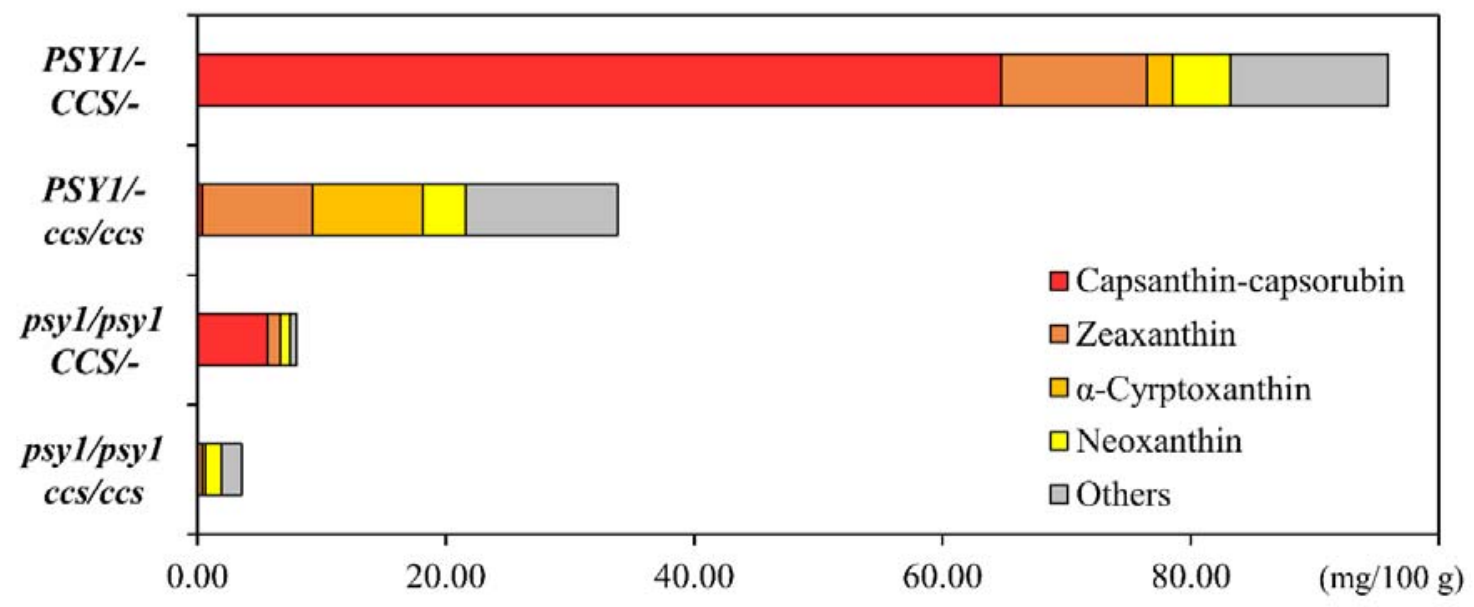

Fig. 4. Carotenoid profiles of each $\mathrm{F}_{2}$ genotype. 
bioRxiv preprint doi: https://doi.org/10 1101/797977; this version posted October 8,2019 . The copyright holder for this preprint (which was not certified by peer review) is the author/funder, who has granted bioRxiv a license to display the preprint in perpetuity. It is made available under aCC-BY-NC-ND 4.0 International license.

\footnotetext{
Functional analysis of Phytoene synthase 2 in pepper fruit
}
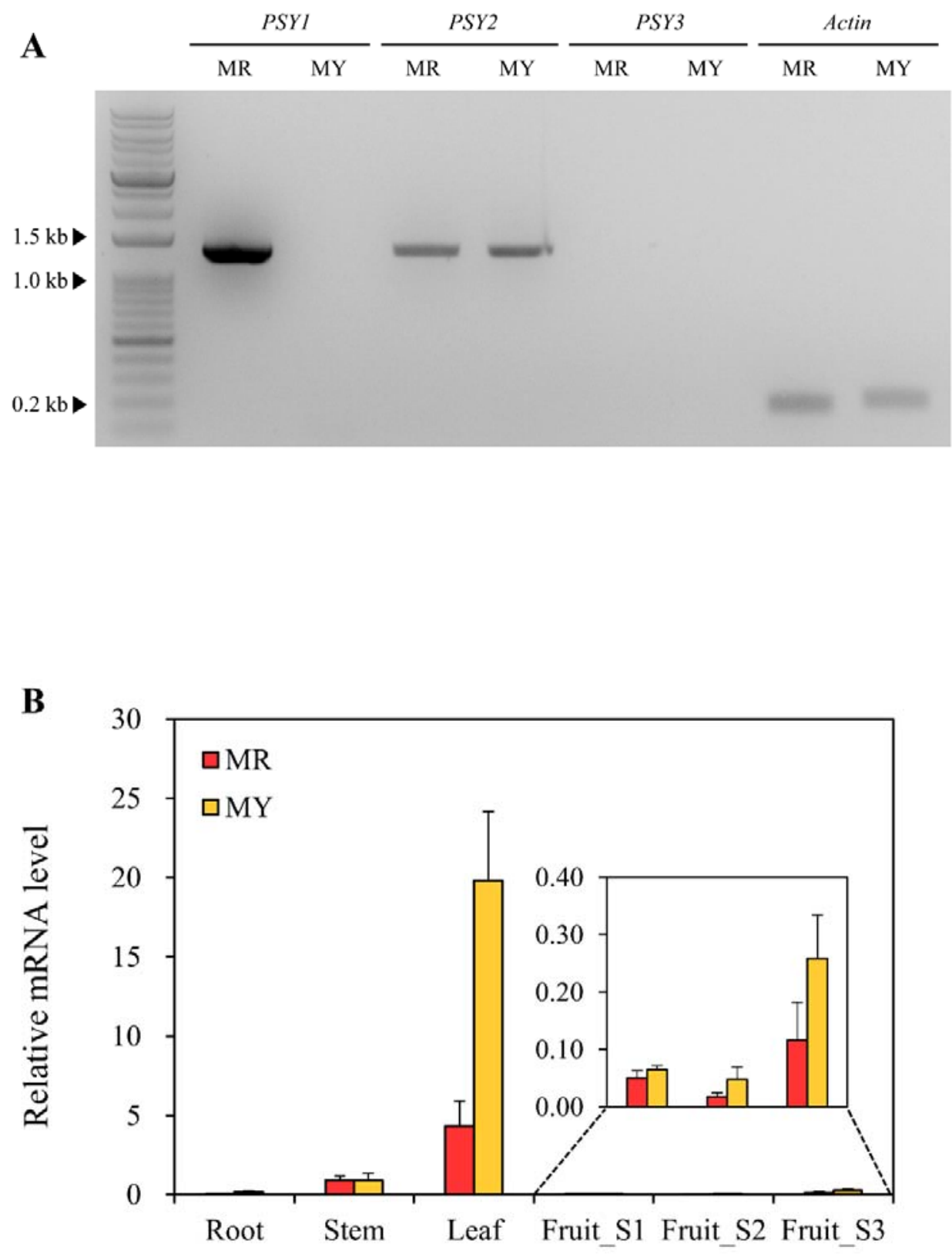

Fig. 5. Expression pattern of the $P S Y$ genes in various tissues. 
bioRxiv preprint doi: https://doi.org/10.1101/797977; this version posted October 8, 2019. The copyright holder for this preprint (which was not certified by peer review) is the author/funder, who has granted bioRxiv a license to display the preprint in perpetuity. It is made available under aCC-BY-NC-ND 4.0 International license.

Functional analysis of Phytoene synthase 2 in pepper fruit

A

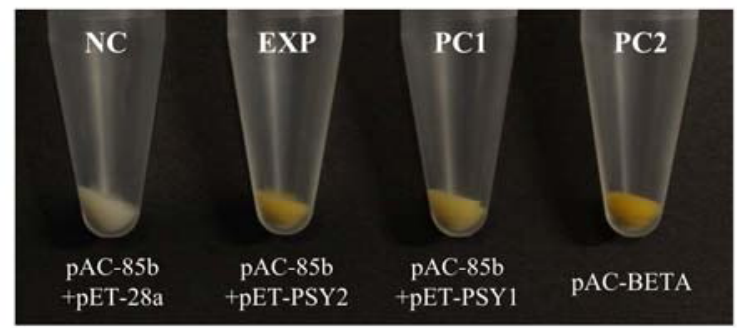

C

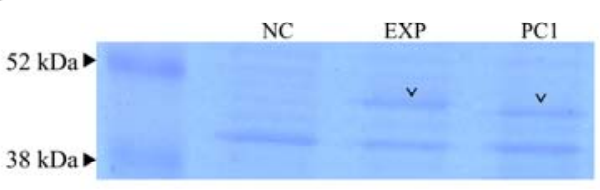

PSY

Control

SY
B

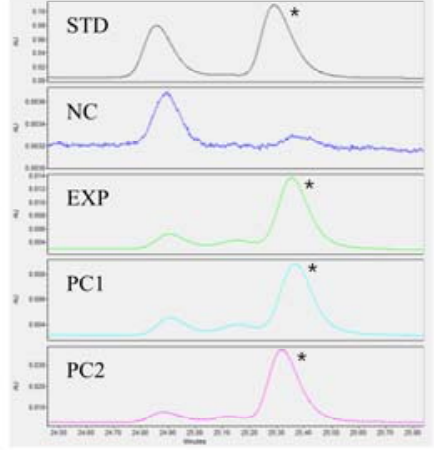

Fig. 6. Complementation assay for PSY2 in E. coli.

$\mathrm{NC}$

EXP

PC1

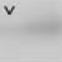

$\checkmark$ 
bioRxiv preprint doi: https://doi.org/10.1101/797977; this version posted October 8 2019. The copyright holder for this preprint (which was not certified by peer review) is the author/funder, who has granted bioRxiv a license to display the preprint in perpetuity. It is made available under aCC-BY-NC-ND 4.0 International license.

Functional analysis of Phytoene synthase 2 in pepper fruit

A
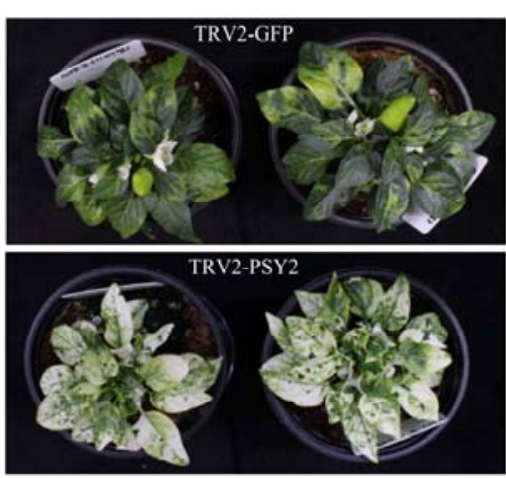

C

TRV2:GFP TRV2:PSY2-1 TRV2:PSY2-2 TRV2:PSY2-3

PSY2

Actin

$$
\text { tin }
$$

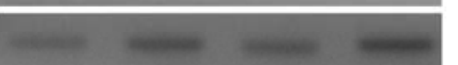

B
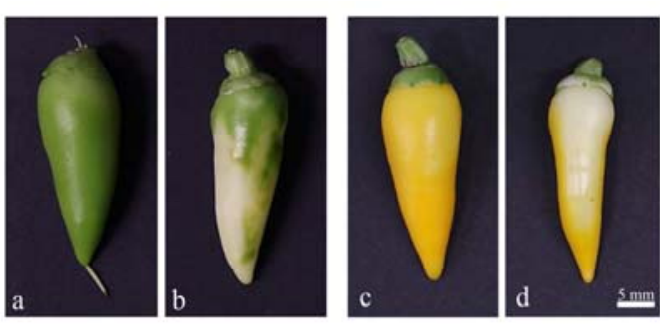

D

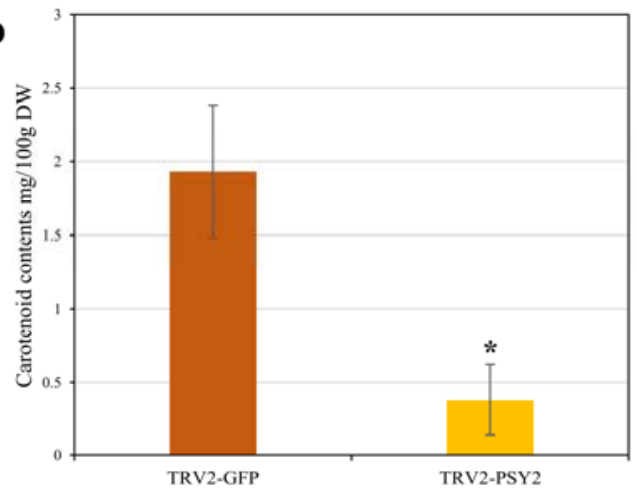

Fig. 7. VIGS of $P S Y 2$ in MY. 
bioRxiv preprint doi: https://doi.org/10.1101/797977; this version posted October 8,2019 . The copyright holder for this preprint (which was not certified by peer review) is the author/funder, who has granted bioRxiv a license to display the preprint in perpetuity. It is made available under aCC-BY-NC-ND 4.0 International license.

\footnotetext{
Functional analysis of Phytoene synthase 2 in pepper fruit
}

\section{Supplementary tables}

Table S1. List of primers used in the SCAR marker analyses of PSY1 and CCS.

\begin{tabular}{cccc}
\hline Marker & Primer sequence (5' to 3') & Position (Zunla Ch4) & Amplicon (bp) \\
\hline PSY1-MR-F & ATGGTTGTGCTGACAATGATTGATG & $205,345,058-082$ & 1,187 \\
PSY1-MY-F & GATTTTGAATCTCCAACACACAAGC & $205,325,421-445$ & 876 \\
PSY1-COM-R & GAGTCCACATTAGCAAAACACATGA & $205,346,244-220$ & - \\
\hline CCS-MR-F & AATGTTATGGCTATTGGTGGGACTT & $227,702,924-900$ & 374 \\
CCS-MY-F & TGCAGTGAACTGCTGCAGAAAC & Not available & 787 \\
CCS-COM-R & TTAGAGGCATGTCCAAAAAGGTACA & $227,702,551-575$ & - \\
\hline
\end{tabular}




\section{Supplementary figure legends}

Fig. S1. Vector information used in the color complementation assay. pAC-BETA contains the CrtE, CrtY, CrtI, and CrtB carotenoid pathway genes from Erwinia herbicola, and thus causes $\beta$-carotene production in $E$. coli. The pAC-85b vector lacks $C r t B$, a $P S Y$ homolog, and cannot cause the biosynthesis of $\beta$-carotene. For the expression of PSY2 derived from MicroPep, the pET-28a(+) vector containing the $T 7$ promoter was used.

Fig. S2. SCAR marker genotyping of PSY1 and CCS. Marker genotype of PSY1 (A) and CCS (B) in the parental lines MR and MY, an $\mathrm{F}_{1}$ hybrid, and six representative $\mathrm{F}_{2}$ plants. For PSY1, a bigger band (1,187 bp) is a representative of the MR-type allele, while a smaller band (374 bp) is a representative of the MY-type allele in $C C S$.

Fig. S3. Amino acid sequence alignment of pepper and tomato PSY1 and PSY2. Asterisks (*) indicate an identical residue between the sequences.

Fig. S4. SCAR marker genotyping of the accessions from which PSY1 was not previously amplified in study of Jeong et al. (2018). (A) The primer binding sites in a genomic diagram. Common forward primer (blue) and distinct reverse primers (red and yellow, respectively) were used for each template. (B) Results of the SCAR marker test. Among the 18 accessions in which PSY1 was not amplified, 15 were revealed to possess a structural variation identical to MY. The other three accessions were not amplified.

Fig. S5. HPLC profiles of the carotenoid extracts obtained from the VIGS-treated MY plants. Both TRV2-GFP- (left) and TRV2-PSY2-inoculated (right) mature fruits contained lutein as a major component. Au, absorbance units. 
bioRxiv preprint doi: https://doi.org/10.1101/797977: this version posted October 8 2019. The copyright holder for this preprint (which was not certified by peer review) is the author/funder, who has granted bioRxiv a license to display the preprint in perpetuity. It is made available under aCC-BY-NC-ND 4.0 International license.

\section{Supplementary figures}

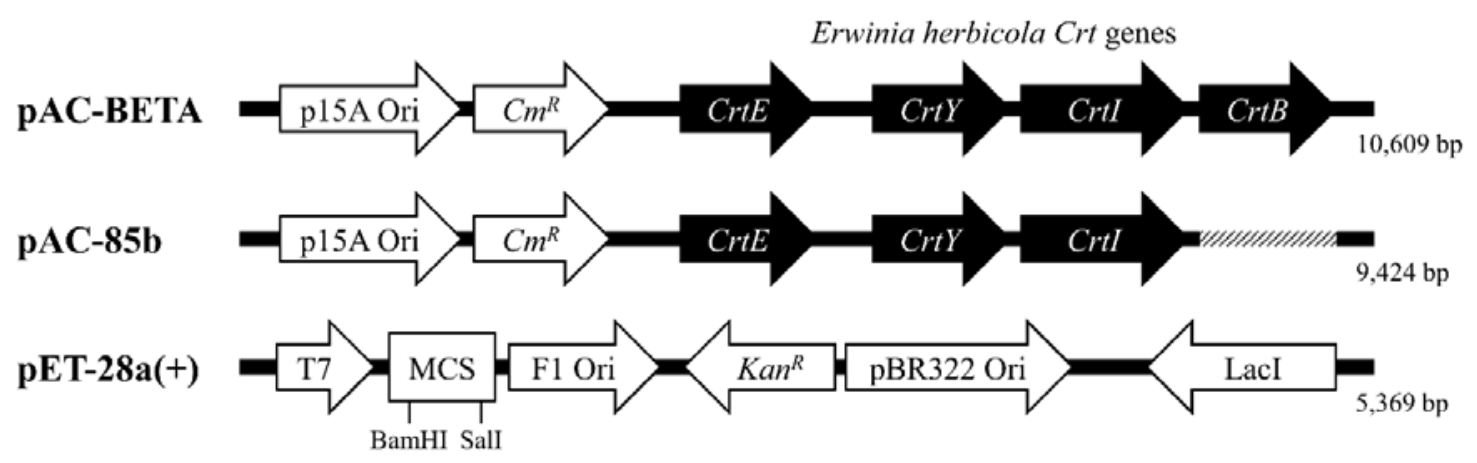

Fig. S1. Vector information used in the color complementation assay. 
bioRxiv preprint doi: https://doi.org/10.1101/797977; this version posted October 8,2019 . The copyright holder for this preprint (which was not certified by peer review) is the author/funder, who has granted bioRxiv a license to display the preprint in perpetuity. It is made available under aCC-BY-NC-ND 4.0 International license.

Functional analysis of Phytoene synthase 2 in pepper fruit
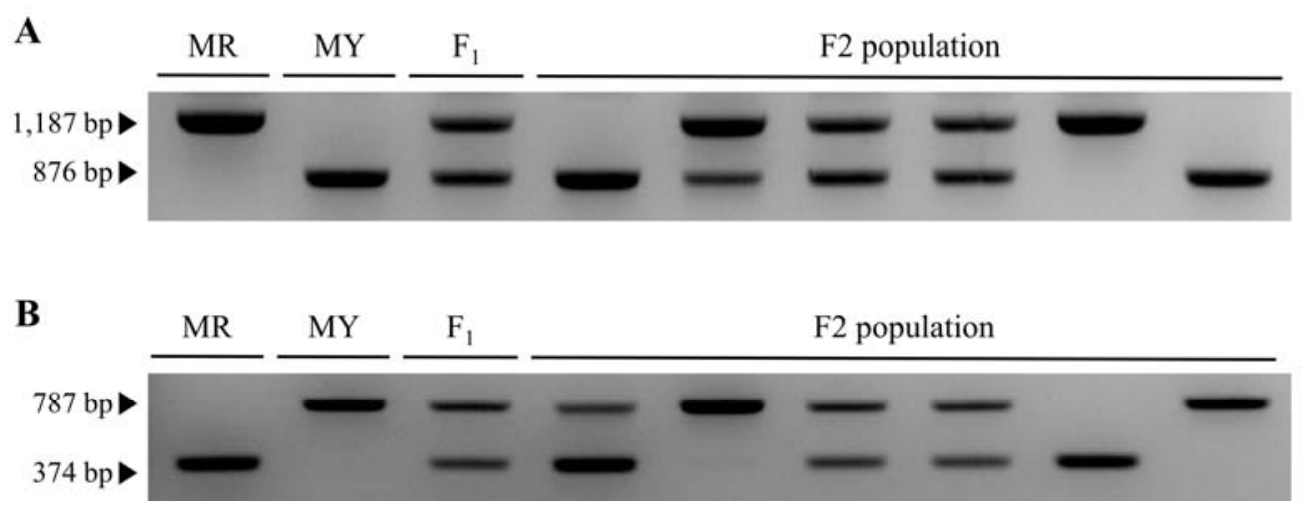

Fig. S2. SCAR marker genotyping of $P S Y 1$ and $C C S$. 
bioRxiv preprint doi: https://doi.org/10.1101/797977; this version posted October 8, 2019. The copyright holder for this preprint (which was not certified by peer review) is the author/funder, who has granted bioRxiv a license to display the preprint in perpetuity. It is made available under aCC-BY-NC-ND 4.0 International license.

Functional analysis of Phytoene synthase 2 in pepper fruit

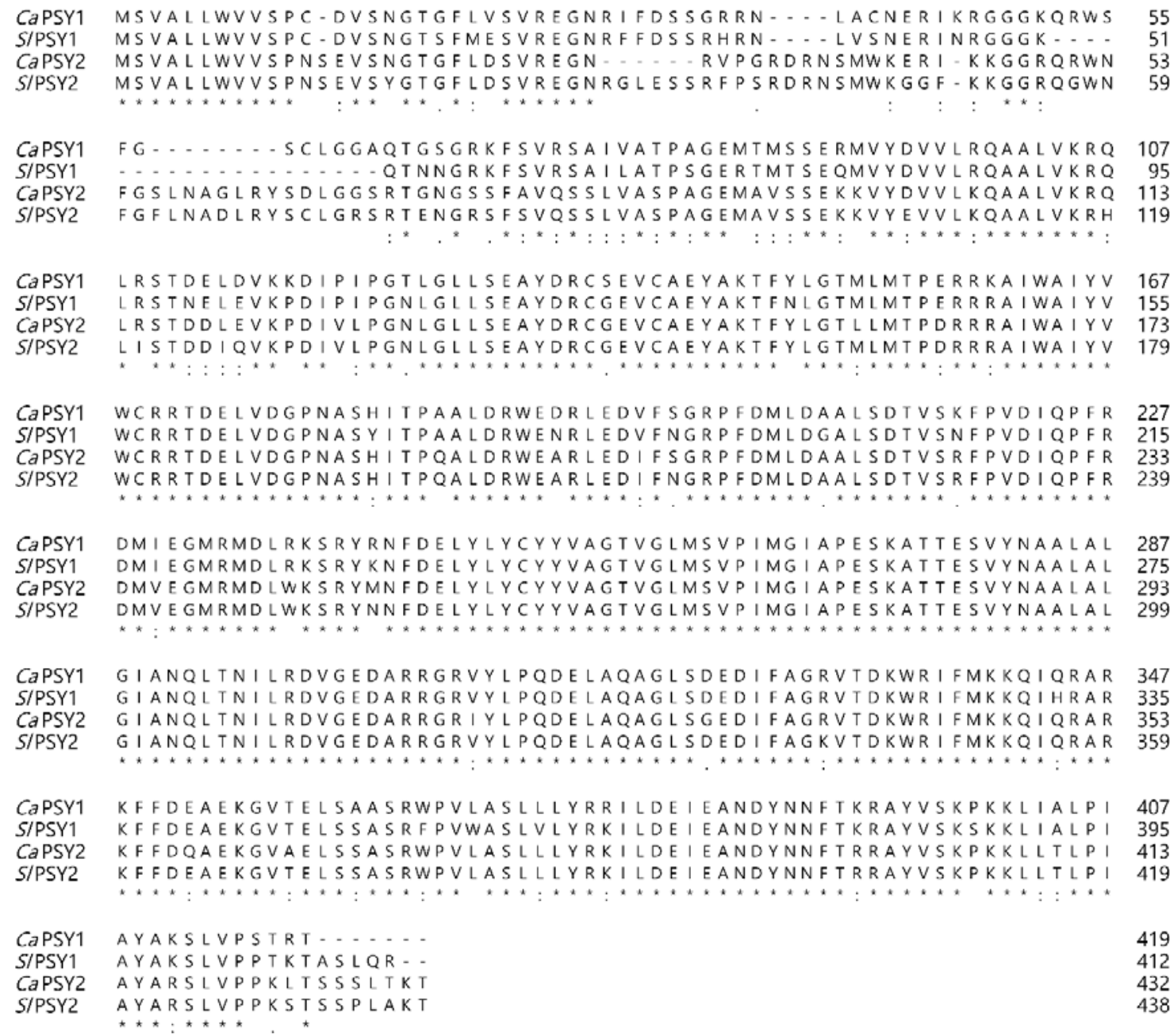

Fig. S3. Amino acid sequence alignment of pepper and tomato PSY1 and PSY2. 
bioRxiv preprint doi: https://doi.org/10.1101/797977; this version posted October 8, 2019. The copyright holder for this preprint (which was not certified by peer review) is the author/funder, who has granted bioRxiv a license to display the preprint in perpetuity. It is made available under aCC-BY-NC-ND 4.0 International license.

A

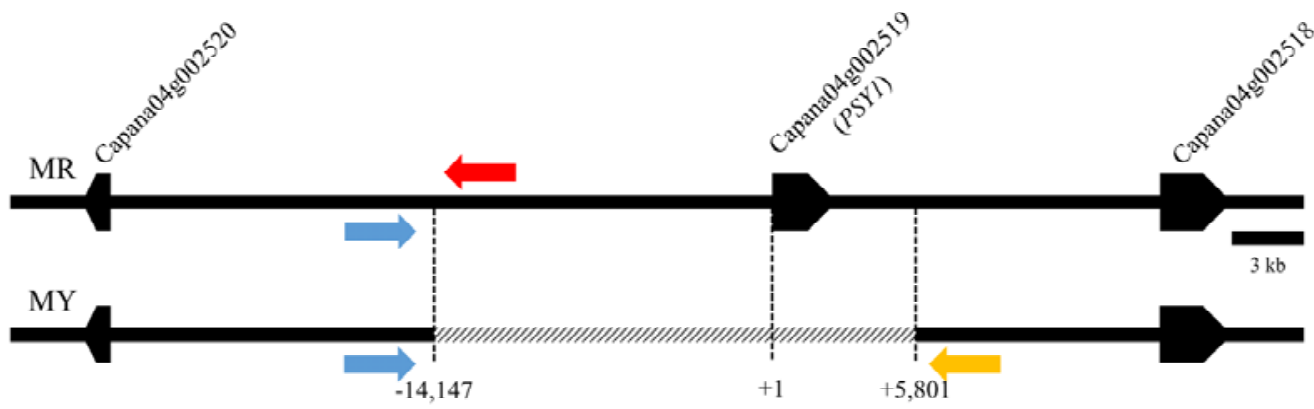

B

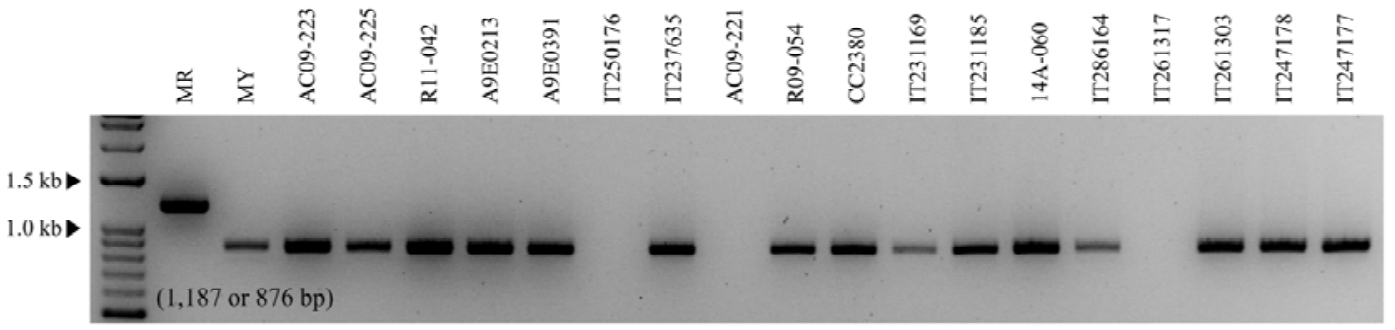

Fig. S4. SCAR marker genotyping of the accessions from which PSY1 was not previously amplified. 
bioRxiv preprint doi: https://doi.org/10.1101/797977; this version posted October 8,2019 . The copyright holder for this preprint (which was not certified by peer review) is the author/funder, who has granted bioRxiv a license to display the preprint in perpetuity. It is made available under aCC-BY-NC-ND 4.0 International license.

\footnotetext{
Functional analysis of Phytoene synthase 2 in pepper fruit
}
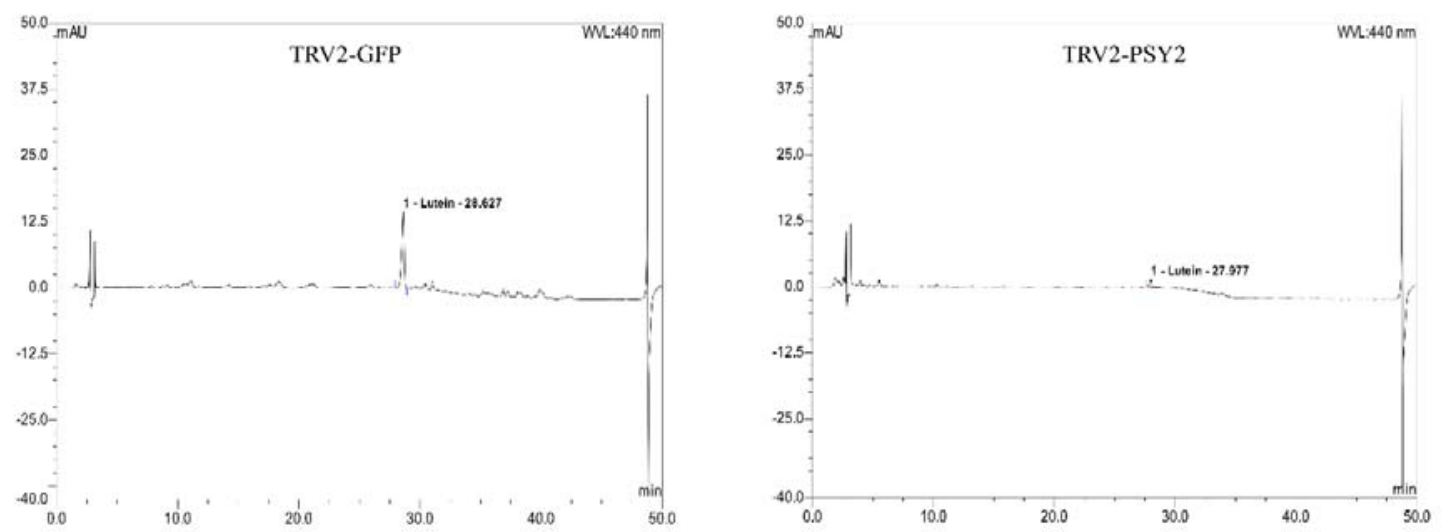

Fig. S5. HPLC profiles of the carotenoid extracts obtained from the VIGS-treated MY plants. 
Appendix 1. LTR retrotransposon sequences discovered in the MY CCS sequence.

/1-1,333 CCS N-terminal; 1,334-1,339 TSD; 1,340-2,381 LTR; 7,164-8,263 LTR; 8,264-8,269 TSD; 8,270-8,427 CCS C-terminal

\begin{tabular}{|c|c|c|c|c|c|c|}
\hline 1 & ATGGA A ACCC & & & & & \\
\hline 61 & TATAGTTTCA & A ACACAACTC & САСТTТТССА & A A TCCA ACCA & AАCAAAAAGA & TTCAAGAAAG \\
\hline 121 & T TC С А T A T A & GAAACAAAAG & CAGTACACAT & T T T T G T A GCT & T T C T T GATTT & $\mathrm{AGCACCCACA}$ \\
\hline 181 & TCAAAGCCAG & A GTCTTTAGA & TGTTA ACATC & TCA TGGGTTG & A T ACTGATCT & GGACGGGGCT \\
\hline 241 & GAATTCGACG & TGATCATCAT & TGGAACTGGC & CCTGCCGGGC & TTCGGCTAGC & TGAACAAGTT \\
\hline 301 & TСТАA А Т А G & GTATTAAGGT & T G T T GCGT T & GACCCTTCAC & CACT T TCCAT & GTGGCCA \\
\hline 361 & A ATTATGGTG & T T TGGGTTGA & TGA GTTTGAA & AAGTTGGGAT & TAGAAGATTG & TC T A GATCA T \\
\hline 421 & A AGTGGCCTG & TGAGTTGTGT & TCATATAAGT & GATCACAAGA & СTA A GTATTT & GGACAGACCA \\
\hline 481 & TATGGTAGAG & TAAGTAGAAA & GAAGTTGAAG & T T GA A A T T G T & TGAATAGTTG & TGTTGAAA A T \\
\hline 541 & AGAGTGAAGT & TTTATAAAGC & CAAGGTTTTG & AAAGTG & ATGAAG & T GA G T \\
\hline 501 & ATTGTTTGTG & ATGATG & GAAGATAAGC & GGTAGC & $\mathrm{GC}$ & $\mathrm{AAC}$ \\
\hline 661 & GT GA T T & GT A & TGA & ATG & G T & $G G$ \\
\hline 721 & А T T T TAGCAG & A A GTTGATAA & TC A T C C A T T T & GATTTGGATA & A A A T GATGCT & TA T G GATTGG \\
\hline 781 & A GGGATTCTC & ATTTAGGTAA & TGAGCCATAT & CTGAGGGTGA & AGAATACTAA & $\mathrm{AGAACCAACA}$ \\
\hline 841 & TTCTTGTATG & CAATGCCATT & TGATAGGAAT & TTGGTATTCT & TGGAAGAGAC & TTCTTTAGTG \\
\hline 01 & AGTCGGCCTA & T GT T A T & TATGGAAGTG & AAAAGAAGGA & TGGT & CA T \\
\hline 61 & TTGGGGA & A AGTG & T G A G & $\mathrm{AGT}$ & $\mathrm{AC}$ & $\mathrm{iGA}$ \\
\hline 021 & $\mathrm{CCACTTCCGC}$ & GG A T TCCTCA & А А ATGTTATG & GCTATTGGTG & GGACTTCAGG & GATAGT TCA T \\
\hline 081 & CCATCGTCTG & GGTACATGGT & GGCTCGTAGC & ATGGCATTGG & $\mathrm{CACCAGTACT}$ & GGCTGAGGCO \\
\hline 141 & A TCGTCGAAA & GCCTTGGCTC & AACAAGAATG & ATAAGAGGGT & СТСААСТТТА & CCATAGAGTT \\
\hline 201 & TGGAATGGT T & T G T G GC & GGATAGAAGA & CGTGTTAGAG & T T G & A T G \\
\hline & GAGACTTTGT & TGA A GCTTGA & TTTGGAAGG T & ACTAGGAGAT & TGTTTGATGC & T T TCT T TGA T \\
\hline, 321 & GTTGATCCCA & AGTACTGGCT & GTTGGGTTCA & TA GTGTGTTG & AATGGAAAAT & GGAGAAACCT \\
\hline ,381 & AAGTGAAGGG & $\mathrm{AAGGAGACAC}$ & CCAAATTGGA & A A GTGTACTC & T T T GCTAAGG & A A A GTTTACT \\
\hline 441 & С T TCTCCCAC & АTTGGTGGAA & GAAGAGAACT & TTAAAGTGTT & TAAAAGTGAA & ACACTTACTT \\
\hline & CACATGGTAA & GTGAGGCAAG & GAAATAGAGA & TGCCTCGCGC & CGTCGTCGTC & G TCGCTCGCT \\
\hline & CGGCTTGGCT & TCGGCT TCGG & A T T T GGATT T & GGATTTGGTC & A A ATGATCGA & TCGATGAGA T \\
\hline & СТАТTTTTTG & GACAAAATTT & ATTTGACGAA & A ATCTGAATA & TGTGTAAAC & GCAGGAAATT \\
\hline
\end{tabular}




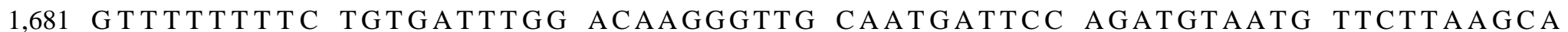
1,741 GATGCACTGT TTGACGAACA GATGCACTGT TTCATGAATA GATGCTGCTG AAAGTTGCGA 1,801 TTCTTCATGA AACAACACAC TGTTTCATCC GAAATGACAT GCCTGTTCAG AAACAGTCAC

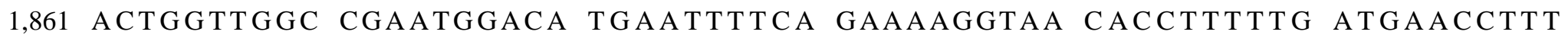
1,921 GTCTCTCTTC GGAAGAGACA TCACTTGGCT ATAAAAACCT GCTTTGATTC ACAGGTTTTA 1,981 ATACAGAATT TTTCAGATTA CAAAACATTC TTCTTGTCTT AAAAATACTC CAAGTGTGAT 2,041 CATACAAACC GTGAGTGTGT TCGAAGAATC TGCCTATTTG AGgTACCGCT ATAGTCGGAT 2,101 TGAAGGCCAT TTtATCCTGG GAGgAAAATT CCACAACCTT GgGTACAGTG AGgGGAATtA 2,161 TTTCCTTAAG GAAAGTCCGT GAATTCGGAT GACTTGGCCT TAACAACATT TCTGTTTCAT

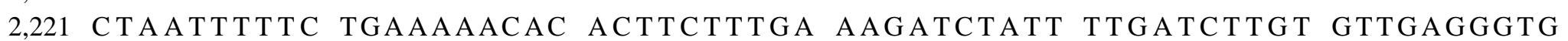
2,281 TTACTTAACT TCATAACGTT CTTGTTTTGT ACTTGACCTA GCGTTGAAGT TGTGTTTCTA 2,341 TAtTATACAG ATtgTACGTA CCCGTATCGg CGgTGGATAA CAATCTTAAG GAAATAATCC 2,401 TTGGAATCTG TATAACTTGT TTTTGGAGAT TAAAGCCTAT GCTTACTACT CCGTTTGAAT 2,461 TTAACTTGTG ATTAGAAGAC ATAAAATCTT CATCAAAAGT TGAAGTTCAC TCGATTGACG 2,521 ATTGGAAGTT ATAAAAACTT CGTCGTTAAT TAGAAACAAG AAGGAAAAAC TTATAAAGTT

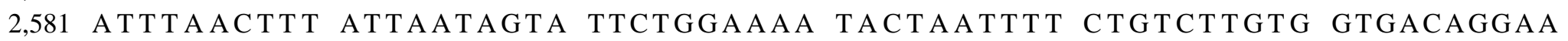
2,641 AAATGACAAC TGAAgGTCAA ATTATGAgTG CAACAACGTC GgTgGgGgCA ACTAACATTG 2,701 CCACATCTAG TCGCACAACT GCTCCGCCAT CGATGGCCCC GGCGGAGAAG CCCGGAAAAT 2,761 TтTCTGGCAT CGACTTCAAA CGGTGGCAAC AAAAgAtgTt CTTTTATCTC ACCACGTTAT 2,821 GTCTACAAAg GTtCACTAGT GAAGATGCAC CCGAGgTACC CGAgGgaACC TCGGACAAGg

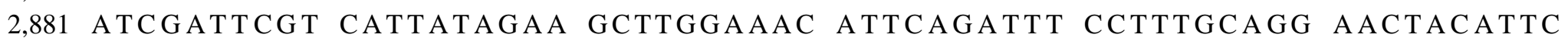
2,941 TGAGCGGTCT CCAAGATGAT CTCTATAATG TCTATAGTGG GACCAAGACA GCAAAAGAAC

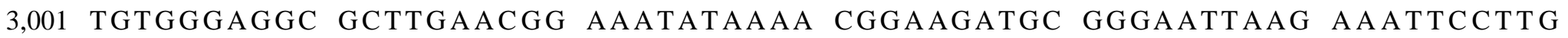
3,061 TTGCACGATT CCTGGACTTT AAAATGATTG ATAGCAAATC TGTTGTCTCT CAAGTACAGG 3,121 AGTTGCAAGT CATCATACAT GATCTCCTAG CAGAAGGTTT AATTGTGAAT GATGCTTTTC 3,181 AAgTAGCAGC AATGGTTGAG AAGCTACCAC CTTTGTGGAA AGACTTCAAA AACTACTTAA 3,241 AgCATAAGCG CAAGgAgATG ACCGTTGAAg ATCTTATTGT TCGACTTCGg ATtGAAGAAG 3,301 ACAATAAAGC TGCCGAAAgA AgGtCAAAgG GAAATTCTGC AATGAATGGA GCACATATTG 3,361 TAgAAGATGG CCAAAACAAC TCGAAGAAAA GAAAGAATGT TGAACATGGA AGCAATCATC

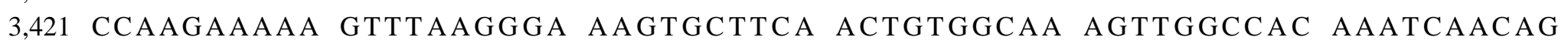

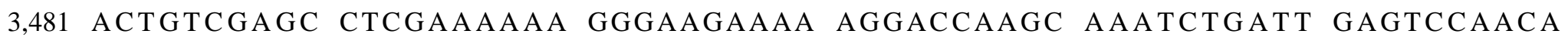




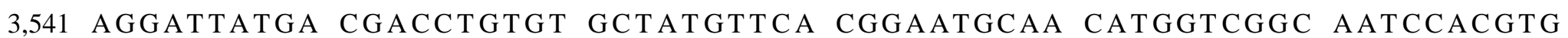
3,601 CTtgGtgGat GgattCAgGg GCCACACGCC ATGTCTGCGC AAgCAAAgAg TTGTTCTCGA 3,661 CATATGCTCC GGCTCAAGCG GAAGAAACAA TATACATGGC CAACTCCGCG ACTGCTAAGG 3,721 TGGAGgGAAT AgGAAAAGTT TGCCTAAAGA TGACATCTGG AAAgGTTTTG ACACTAAATA

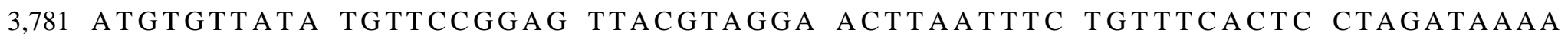
3,841 ATgGTtTCAA ATGTGTAACC GTtTCTGGAA AAATAGTAGT TAgCAAAgGA GAAATGTATG 3,901 TAGGAAAAGG CTATCTCGAG GAAGGCCTTT ATAAGATGAA TGTAATGAAT ATTGAAATGA 3,961 ATAAAAATTC AAATTCTTCT TACTTGCTTG AGTCTTATAA TTTATGGCAT GAACGTTTAG 4,021 GCCATGTTAA TTACAAAACG TTACGAAAAC TGATTAACTT AgAAgTtTTG CCAAATtGTG 4,081 AgtgCAATAA ATCTAAgtgt CAAACGTGTG TAGAATCAAA GTATGCTAAG CATCCTTATA 4,141 AGTCTGTTGA AAgGAATTCC AATCCCTTAG ACTTAATACA CACTGACATT TGTGATATGA 4,201 AGTCAACACC ATCACGTGGT GGAAAAAAgT ATTTCATAAC TTTTATTGAC GATTGCACTA

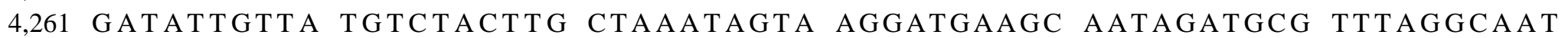

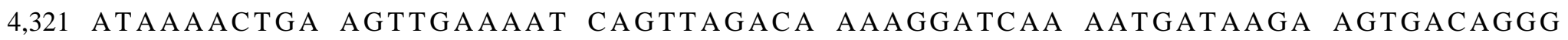
4,381 GCGGAgAATA TGAATCTCCC TTTGCGCAAA ATATGTGTAG AgAATGgAAT AATCCATCAA 4,441 ACTACGGCCC CCGTATTCAC CTCAATCTAA TGGAATTGCT GAAAgGAAAA ATCGAACTTT 4,501 GAAGGAAGTG ATGAATGCCT TACTAATAAG TTCTGGTTTA CCGCAAAACT TGTGGGGGGA 4,561 GGCTATCCTT ACGGCCAATC GTATACTCAA TAGAGTTCCC CATAGTAAGA CACAATCAAT 4,621 TCCTTACGAA AAATgGAAAg GAAGgAAACC CAACTTGAAA TATTtCAAAg TGTGgGgGtg 4,681 TCTAGCGAAg GTtCAAgTtC CTATATCTAA AAgGgTtAag ATAgGACCTA AAACGGTGGA 4,741 CTGCGTGTTC ATAGgATATG CTAAAAgGA TAAAGCATGT CGATTtTTGG TTCATAAATC 4,801 CGAACATTCG GATATAAATG AAAATACGGT AATTGAATCA GATAATGCTG AATTCTTTGA 4,861 AAACATTTAT CCGTATAAAA CTAGACATGA ACAGTCTAGT GgaggatCTA AACGACCCCG 4,921 AgATGAACCA AgTGAgAATG TACATAATGA AgAAAATCCA AgACGTAGTA CACGTCAAAG 4,981 AACATCAACT TCGTTTGGAT CGGATTTTGT AACGTTTCTC TTAGAAAATG AGCCTCGAAC 5,041 GTtTAAAgAA GCGATGTCGT CATCAGACTC ATCCTTTTGG AAAgAgGCAG TCAATAGTGA

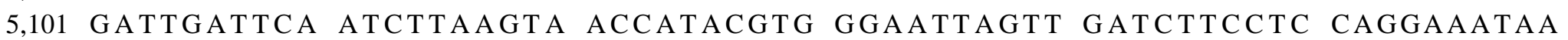
5,161 ACCTTTAGgG TCTAAATGgA TCTTCAAAAg GAAAATGAAA ACGgATgGTT CTATTGACAA 5,221 ATACAAGgCA AgACTTGTAG TAAAAgGCTT CAATCAAAAA GAAGgTCTTG ATTACTTTGA 5,281 TACATACTCG CCAGTGACAA GGATAACCTC AATTCGAATG TTAATTGCCT TGGCGGCAGT

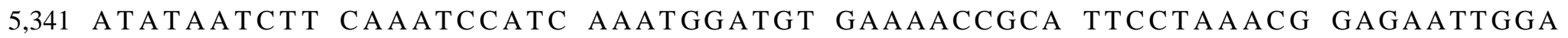




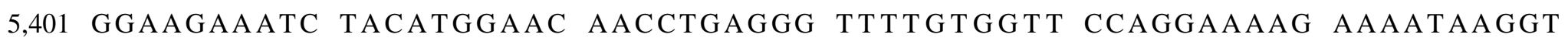
5,461 GTGTAAACTT GTTAAGTCAC TTTATGGACT AAAACAAGCA CCCAAGCAAT GGCATGCAAA 5,521 GTTTGACCAA ACCATGTTGG CAAACGGATT CAAGATAAAT GAATGTGATA AATGTGTGTA 5,581 TATTAAGGAC ACACCAAATC ACCAAGTCAT TGTATGTTTA TATGTGGATG ATATGTTGAT 5,641 CATCAGTAGA GACATtTGTG ACATAAATGC AACCAAACAA ATGCTCGAGA GCAAGTTtga 5,701 TATGAAAgAC CTCGgAgTTG CAGATGTGAT CTTAGgTATA AGAATCCATC GAACTCTACA 5,761 AGgGTTAGCA CTGTCACAGT CTCATTATAT CGAAAAAGTA CTTGACAAGT TCAAGTATAT 5,821 GGAGTtCGAT ATtgCCAAGA CTCCATTGGA TGCGAACTTT GCACTTCGGA AAAATGAAGG

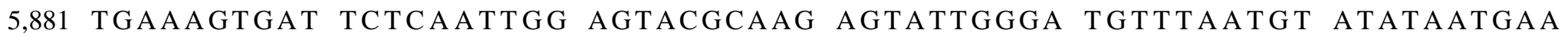
5,941 CTGTACACGA CCAGACATAG CATGCACTAT CAGTAAATTG AGTCGGTACA CGAGTAATCC 6,001 CAATAAAACT CACTGGATGG CAGTGAAAAG AGTTTTGGGT TATCTTAAAT ACACTCGAGA 6,061 CTATGCTTtg CATtATAATA AATATCCAGC GgTACTTGAA GgatATAgTG ATGCAAATtG 6,121 GATCACCGGA TCGAACGAAG TAAAATCCAC AAGTGGATAT GTATTTACTA TCGGTGGAGG 6,181 AgCAgTtTCT TGGAAATCGT CGAAACAGAC TTGTATCGCT CGCTCTACAA TGGAATCTGA

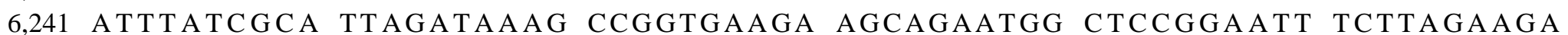
6,301 TAтTCCTTAT TGGCCCAAGC CAGTGGCACC AGTATGTATA CACTGTGATA GCCAAGCGGC

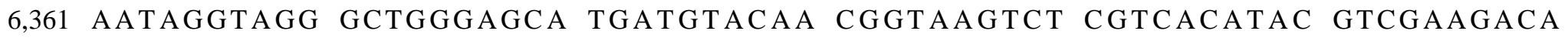
6,421 TAATACCGTT AGAGAACTTC TCTCTAGTGG AATTATTACT ATAGACTATG TAAAGTCAAA 6,481 GgAtAATGTG TCGGATCCAC TTACAAAAgG CCTATCTAGA GAAGgAgTAG AAAGgACATC 6,541 CAAGgGAATG GGTTTAAGgC CTAGgACAAG TCAGCATGGC GgTAACTCTA CCTAGCAGAC 6,601 TGGAGATCCC AAGAGCTAGg TTCAAGgAGA ACAAACAAAG TTATGTCTGA CAGGTTCAAC 6,661 ATtGTCATTC ACCCAACTCA TTCTCATGAT GTAGACAATG TATAGTAAAC CAGGATAAGA 6,721 CTTAAgGTGA AAAgTCTTTT AATGATTATC TAAATTTGGC AGATTTGACC AAATAGTTCA 6,781 AgCTAAAGgA TTGAAACGTT TAgAAATCAC CTATATGAGG GCGAAGTGGA AGCCGCTTCA 6,841 AAgAgAatgT TAGTAAAgGC CTATTCTCTA AGCTCTCATG AAACCGGGAC GTGTTCATGG 6,901 CTGAAAAGAA CAAAACCGTA AgAACCATAA ATGGTAAAAg GCTGATtgTG TGACATGTGT 6,961 TGTCTAGGTG TACATTAAAG CTCGACGgTT CAAAGATATC AAATCTACCG ATTGACCGAG 7,021 TGCATCCGAT ACATGTTCAC TACGGAAAgT TCAAAGgGAA ACCCACTTAT CCAGATGCAA 7,081 TCAGTCCTTG CTTGATGATC ACATACTGTC CGTAAACGAT TTTTGAAAAA AAAAAATAGC 7,141 CATTCCCCAT TCATGTGGGG GATTGTTGGG TTCATAGTGT GTTGAATGGA AAATGGAGAA

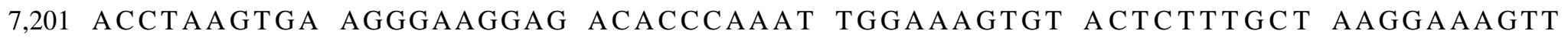


7,261 TACTCTTCTC CCACATTGGT GGAAgAgAg AACTTTAAAg TGTTTAAAAg TGAAACACTT 7,321 ACTTCACATG GTAAGTGAGG CAAGgAAATA GAGATGCCTC GCGCCGTCGT CGTCGTCGCT 7,381 CGCTCGGCTT GGCTTCGGCT TCGGCTTCGG CTTTGGATTT GgatTTGgAT TTGGATTTGG 7,441 TCAAATGATC GATCGATGAg ATCTATTTTT TGGACAAAAT TTATTTGACG AAAATCTGAA 7,501 TATGTGTAAA ACGCAGgAAA TTGTTTTTTT TCTGTGATTT GGACTCCATT TATATGCATG 7,561 CAGTGAACTG CTGCAGAAAC GTTAAAGgGT TGCAATGATT CCAGATGTAA TGTTCTTAAG 7,621 CAGATGCACT GTTTGACGAA CAGATGCACT GTTTCATGAA TAGATGCTGC TGAAAGTTGC 7,681 GATTCTTCAT GAAACAACAC ACTGTTTCAT CCGAAATGAC ATGCCTGTTC AGAAACAGTC 7,741 ACACTGGTTG GCCGAATGGA CATGAATTTT CAGAAAAGGT AACACCTTTT TGATGAACCT 7,801 TTGTCTCTCT TCGGAAGAGA CATCACTTGG CTATAAAAAC CTGCTTTGAT TCACAGGTTT 7,861 TAATACAGAA TTTTTCAGAT TACAAAACAT TCTTCTTGTC TTAAAAATAC TCCAAGTGTG 7,921 ATCATACAAA CCGTGAgTGT GTTCGAAGAA TCTGCCTATT TGAGgTACCG CTATAGTCGG

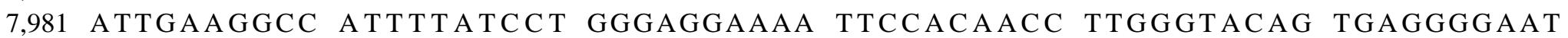
8,041 TATTTCCTTA AgGAAAgTCC GTGAATTCGG ATGACTTGGC CTTAACAACA TTTCTGTTTC 8,101 ATCTAАтTTт TCTGAAAAAC ACACTTCTTT GAAAGATCTA TTTTGATCTT GTGTTGAGGG 8,161 TGTTACTTAA CTTCATAACG TTCTTGTTTT GTACTTGACC TAGCGTTGAA GTTGTGTTTC

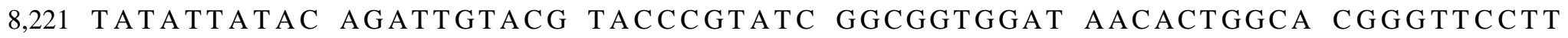
8,281 TCTTCAAGAT TGTCTGTCAA AGAACTTGCT GTACTCAGTT TGTACCTTTT TGGACATGCC 8,341 TCTAATtTgG CTAGgTtgGA TATtgTtACA AAgTGCACTG TCCCCTTGgT TAAACTGCTG 8,401 GGCAATCTAG CAATAGAGAG CCTTTGANNN 